\title{
Kinematic Viscosity Prediction Guide: Reviewing and Evaluating Empirical Models for Diesel Fractions, and Biodiesel-Diesel Blends according to the Temperature and Feedstock
}

Shella Santos ( $\square$ shellamaria.santos@gmail.com )

UNICAMP FEQ: Universidade Estadual de Campinas Faculdade de Engenharia Quimica https://orcid.org/0000-0002-8953-7941

Maria Regina Wolf Maciel

UNICAMP FEQ: Universidade Estadual de Campinas Faculdade de Engenharia Quimica Leonardo Vasconcelos Fregolente UNICAMP FEQ: Universidade Estadual de Campinas Faculdade de Engenharia Quimica

\section{Research Article}

Keywords: Empirical Equations, Prediction Method, Biodiesel, Diesel Fraction, Kinematic Viscosity

Posted Date: September 17th, 2021

DOl: https://doi.org/10.21203/rs.3.rs-312015/v1

License: (c) (1) This work is licensed under a Creative Commons Attribution 4.0 International License.

Read Full License 


\title{
Kinematic Viscosity Prediction Guide: Reviewing and Evaluating Empirical Models for Diesel Fractions, and Biodiesel-Diesel Blends according to the Temperature and Feedstock
}

\author{
Shella M. Santos, Maria R.W. Maciel, and Leonardo V. Fregolente \\ School of Chemical Engineering, University of Campinas, Campinas, Brazil
}

\begin{abstract}
Experimental analysis of viscosity can be a straightforward and inexpensive analysis for few samples. However, in industrial processes that have high demands of properties measurements, the determination of viscosity and other properties involves time-consuming with sampling, analysis and availability of results. Also in refineries, the sampling routines for experimental determination of the viscosity of streams are not enough to represent variations that occur in the process, such as the shift of an oil tank in distillation units. In addition, besides requiring cost of operating personnel and laboratory analyst, all of these steps can take up to one shift until the result is available. Therefore, as an alternative, the use of predictive methods of kinematic viscosity are essential. Empirical methods have been used in simulations and design calculations of streams and mixture at industries regarding kinematic viscosity $(\mathrm{KV})$ of petroleum fractions and fuels at different temperatures. However, there are uncertainties about the most accurate method to use at specific condition (temperature, feedstock, volume fraction) which might affect the KV prediction of fuels with unknown composition. Therefore, we assembled and evaluated several methods to predict $\mathrm{KV}$ of different diesel systems. In addition, new methods for predicting KV of diesel fractions at several temperatures were also developed for improving the estimation accuracy. As a result, we developed a guide with suggestions of the most accurate models to be applied for diesel fraction from assays, diesel fractions S500 from blend system at several temperatures, and biodiesel-diesel blends at different temperatures, volume fractions and feedstock.
\end{abstract}

Keywords: Empirical Equations; Prediction Method; Biodiesel; Diesel Fraction; Kinematic Viscosity

\section{Introduction}


Production of petroleum fractions and transportation fuels requires monitoring and control of some properties, such as viscosity. Besides essential for flow and hydraulic calculations, this property is also required during the blending process of petroleum fractions to increase profits through giveaway decreasing, adding less noble fractions, without deviating from fuel specification $[1,2]$.

The examination of kinematic viscosity (KV)at $40^{\circ} \mathrm{C}$ is an important property, especially for fossil diesel, for the well-functioning of a given engine, influencing factors such as droplet size formation at the fuel atomization process for combustion quality [3]. Some concerns related to inadequate viscosity are leakage, in case of low $\mathrm{KV}$, and poor atomization, incomplete combustion, deposit formation, and malfunctioning during cold weather [4]. As such, depending on the type of diesel engines, the kinematic viscosity target of fuels varies from $1.3 \mathrm{~mm}^{2} / \mathrm{s}$ to $4.1 \mathrm{~mm}^{2} / \mathrm{s}$ at $40^{\circ} \mathrm{C}$ for diesel fuel with light middle distillate, with specific sulfur concentration, according to ASTM D975-20a and ASTM 7467-20a [5,6].

Kinematic viscosity is also a crucial property for biodiesel, a biofuel derived from vegetable and animal oils applicable for Diesel engines. The biodiesel is a renewable source that can be an alternative of fossil diesel (non-renewable) in case of petroleum depletion and it is often blended with fossil diesel [7]. The application of biodiesel provides some benefits such as lower carbon dioxide emission and the increase of lubricity of the fuel in the engine, due to its higher KV $[3,8]$. However, the high $\mathrm{KV}$ of biodiesel, which varies according to feedstock, and volume fraction of biodiesel in a blended fuel, diminishes the quality of fuel atomization, and increases the formation of deposits in engines [9-11]. Thus, biodiesel KV must meet the specification, which ranges from $1.9 \mathrm{~mm}^{2} / \mathrm{s}$ to $6.0 \mathrm{~mm}^{2} / \mathrm{s}$ at $40^{\circ} \mathrm{C}$ [12], according to methods ASTM D445 and ASTM D7945 [5]. Those experimental tests depend on temperature and present satisfactory measurement for fluids with Newtonian flow behavior.

Experimental analysis of viscosity can be a straightforward and inexpensive analysis for few samples. However, in industrial processes, the determination of experimental viscosity or any other property involves sampling, analysis and availability of results. Therefore, besides requiring cost of operating personnel and laboratory analyst, all of these steps can take up to one shift until the result is available. Also in refineries, the sampling routines for experimental determination of the viscosity of streams are not enough to represent the variations that occur in the process, such 
as the shift of an oil tank in the distillation unit. In addition, for minimizing giveaway in fuel blending systems, online optimization is necessary, with instantaneous values that is only possible through calculation methods. These methods are applicable for viscosity prediction of streams before and after blending (mixing calculations).

Viscosity prediction of fuels with high accuracy might not be a straightforward calculation, since it depends on its composition, chemical properties of each compound in the mixture [13], their interaction [14], temperature, and type of predictive model. For that, the prediction of kinematic viscosity can be carried out by two different approaches: rigorous calculations and empirical methods.

Rigorous calculations for viscosity prediction are based on theoretical concepts, such as statistical mechanics [15-21]. There are also semi-theoretical models with theoretical basis but also has some adjusted parameters. Rigorous methods might require complex data at molecular level, such as repulsion diameter, intermolecular potential attractive energy, structure theory, molar mass, and so on [22].

Some theories for viscosity prediction were developed based on Brownian motion, and equations of state in function of density and complex parameters such as rigid sphere diameter of the molecules, and coefficients of shear [16]. There is also a theory relating the flow with activation energy so that the calculation includes several parameters such as the molar free energy of activation of flow, molar volume for Newtonian behavior [23, 24]. For non-polar and polar pure liquid viscosity, the corresponding-states method has been applied for equilibrium and transport properties of pure materials [17] and requires critical properties, and size or shape parameter [25].

For hydrocarbon mixtures, rigorous methods also can be used. There are some studies for $\mathrm{KV}$ prediction of mixtures requiring composition content, pressure, temperature, thermal conductivity, some fitted parameters in function of $\mathrm{n}$-alkane and aromatics, molar mass, and critical properties [26-28].

In front of the complexity of theoretical models application, empirical methods are often used in simulations with interactive calculations and project optimization to predict KV based on a correlation between viscosities and other properties. 
KV can also be obtained through conversion model instead of a predictive one applying the standard ASTM D341, which requires only KV at two different temperatures to obtain $\mathrm{KV}$ at specific temperature [29].

For feasibility, predictive empirical methods have been developed requiring as input only properties easily measured and frequently available, such as density and boiling temperature. These methods are highly useful when the composition and other difficult properties are unknown [1,2,30-33]. However, as a drawback, empirical methods are developed for a specific system so that the range of validity is narrow and might not be applicable without restrictions [34].

Some individual studies have been conducted for kinematic viscosity prediction for fossil compounds, such as the development of new correlations for petroleum fraction $[35,36]$, and crude oil blends $[14,37]$. There are also studies with assessment and development of models to predict kinematic viscosity of biodiesel-diesel blends [38-43] and specially a recent evaluation models at $40^{\circ} \mathrm{C}[44]$.

Therefore, due to the abundance of empirical models and numerous individual assessments of KV prediction, we evaluated existing methods at several conditions (temperature, feedstock, volume fraction) to verify the applicability and accuracy of $\mathrm{KV}$ predictive models for various systems, such as diesel fractions, and several biodiesel-diesel blends at different temperatures and volume fraction. We also developed new methods to predict $\mathrm{KV}$ of diesel fractions with higher accuracy then presented existing models. After that, we also developed a guide with indication of the most suitable methods to be used, according to the obtained accuracy represented by the minor $\%$ AAD from each evaluation.

\section{Predictive Models of Kinematic Viscosity}

Viscosity can be predicted by different types of models, such as semi-theoretical, theoretical, and empirical. Semi-theoretical models are based on the principle of corresponding states, applying reduced properties and theoretical models, which are based on models of statistical mechanics [1].

\subsection{Prediction of kinematic viscosity of hydrocarbons}


To predict the kinematic viscosity of hydrocarbons, there are several models that can be applied (Table 1). However, the calculation and the accuracy will mainly depend on the application range of each model and the required input parameters.

Abbot [2] has developed two methods to predict $\mathrm{KV}$ (cSt) at $37.8^{\circ} \mathrm{C}$ and $98.9^{\circ} \mathrm{C}$, applying only API characterization factor ( $K_{A P I}$ and API gravity ( $\left.{ }^{\circ} \mathrm{API}\right)$, shown in Equations (1) and (2). Results from those models presented a deviation of around $10-15 \%$, for petroleum fractions, with $\mathrm{KV}$ from $0.5 \mathrm{cSt}$ to $200 \mathrm{cSt}$ at $100^{\circ} \mathrm{F}, 0.3 \mathrm{cSt}$ to $40 \mathrm{cSt}$ at $210^{\circ} \mathrm{F}$, and with ${ }^{\circ} \mathrm{API}$ from 0 to 25 , and $\mathrm{K}_{\mathrm{API}}$ from 10 to 12.5 [2].

For undefined petroleum fraction, Aboul-Seoud and Moharam [30] have developed a method to predict $\mathrm{KV}\left(\mathrm{mm}^{2} / \mathrm{s}\right)$ at any temperature $(\mathrm{K})$, requiring only mid-boiling point $(\mathrm{K}), T_{b}$, and specific gravity (sg) at $15.6{ }^{\circ} \mathrm{C}$ (Eq.(3)) [30].

With only mid-boiling point $(\mathrm{K}), T_{b}$, it is also possible to predict $\mathrm{KV}\left(\mathrm{mm}^{2} / \mathrm{s}\right)$ of petroleum fractions and hydrocarbons at any temperature $\mathrm{T}(\mathrm{K})$ by applying Mehrotra et al. [1] model (Eq.(4)).

Another model that requires only one input property is the one developed by Puttagunta et al. [45]. Their method (Eq.(5)) requires $\mathrm{KV}\left(\mathrm{mm}^{2} / \mathrm{s}\right)$ at $37.8^{\circ} \mathrm{C}$ and is applicable for fractions with API gravities in excess of 30 degrees and API at low pressure. It is also recommended by the APITDB - American Petroleum Industry - Technical Data Book on Petroleum Refining [45].

With more and different input parameters, the $\mathrm{KV}$ of petroleum fraction can be predicted by Beg et al. [46] method (Eq.(6)), applying parameters A and B, which are obtained from temperature at $50 \%$ volume distilled $\left(T_{50}\right)$ and API gravity. This model can be applied only for data with boiling point from $200{ }^{\circ} \mathrm{F}$ to $850{ }^{\circ} \mathrm{F}$ [46]. Beg and Amin [31] also developed two more models to predict KV, Eq.(7) for heavy petroleum fraction and Eq.(8) for petroleum fraction with boiling point from $95{ }^{\circ} \mathrm{C}$ to $455^{\circ} \mathrm{C}$.

There is also another model to predict the $\mathrm{KV}$ of petroleum fractions at any temperature $\mathrm{T}$ (K) that requires three input properties, such as molecular weight, density at temperature $\mathrm{T}\left(\rho_{T}\right)$, and temperature at $50 \%$ volume distilled $\left(T_{50}\right)(\mathrm{K})$ (Eq.(9)). In case of lack of molecular weight, density and temperature T, authors Fang and Lei [32] have suggested equations to obtain them, using density at $15.6^{\circ} \mathrm{C}\left(\rho_{15,6}\right)$, and $T_{50}$. 
Also, there is a procedure to obtain KV from petroleum fractions by following the ASTM D341 [29] model. For that, one must apply two kinematic viscosities at two different temperatures (Eq.(10)).

There are also two models of $\mathrm{KV}$ prediction at $98.8^{\circ} \mathrm{C}$, which are applicable for heavy oil with density from $929 \mathrm{~kg} / \mathrm{L}$ to $1094 \mathrm{~kg} / \mathrm{L}$, and pour point of heavy oil from $-33{ }^{\circ} \mathrm{C}$ to $15{ }^{\circ} \mathrm{C}$ (Equations (11) and (12)). Eq.(11) requires kinematic viscosity at $60^{\circ} \mathrm{C}$ and density at $20{ }^{\circ} \mathrm{C}$, with $\mathrm{AAD}=1.54 \mathrm{~mm}^{2} / \mathrm{s}$. Eq.(12) only requires kinematic viscosity at $60^{\circ} \mathrm{C}$, with $\mathrm{AAD}=3.72 \mathrm{~mm}^{2} / \mathrm{s}$ [33].

Table 1 - Models to predict kinematic viscosity, $v$, of pure hydrocarbon systems

\begin{tabular}{|c|c|c|}
\hline Model & Equation & $\begin{array}{l}\# \\
\text { Eq. }\end{array}$ \\
\hline Abbot 1 & $\begin{array}{c}\log \left(\mathrm{v}_{37.8}\right)=\left(4.39371-1.94733 \mathrm{~K}_{\mathrm{API}}+0.12769 \mathrm{~K}^{2} \mathrm{API}+3.2629\right. \\
* 10^{-4} * \mathrm{API}^{2}-1.18246 * 10^{-2} * \mathrm{~K}_{\mathrm{API}} *{ }^{\circ} \mathrm{API} \\
0.171617 \mathrm{~K}^{2} \mathrm{API}+10.9943 * \mathrm{API}+ \\
+) \frac{9.50663 * 10^{-2} *{ }^{\circ} \mathrm{API}^{2}-0.860218 * \mathrm{~K}_{\mathrm{API}} *{ }^{\circ} \mathrm{API}}{{ }^{\circ} \mathrm{API}+50.3642-4.78231 \mathrm{~K}_{\mathrm{API}}}\end{array}$ & (1) \\
\hline Abbot 2 & $\begin{aligned} \log v_{98.9^{\circ} \mathrm{C}}= & \frac{8.0325 * 10^{-2} \mathrm{~K}_{\mathrm{API}}+1.24899 *{ }^{\circ} \mathrm{API}+0.19768 *{ }^{\circ} \mathrm{API}^{2}}{{ }^{\circ} \mathrm{API}+26.786-2.6296 \mathrm{~K}_{\mathrm{API}}} \\
& +\left(-0.463634-0.166532 *{ }^{\circ} \mathrm{API}+5.13447 * 10^{-4}\right. \\
& { }^{\circ} \mathrm{API}^{2}-8.48995 * 10^{-3} * \mathrm{~K}_{\mathrm{API}} *{ }^{\circ} \mathrm{API}\end{aligned}$ & (2) \\
\hline Aboul-Seoud and Moharam & $\begin{array}{c}\ln (\ln (\mathrm{v}+0.8))=\mathrm{a}_{1}+\mathrm{a}_{2} * \ln (\mathrm{T}) \\
\mathrm{a}_{1}=4.3414 *\left(\mathrm{~T}_{\mathrm{b}} * \mathrm{sg}\right)^{0.2}+6.6913 \\
\mathrm{a}_{2}=-3,7\end{array}$ & (3) \\
\hline Mehrotra et al. & $\begin{array}{c}\log \log \left(\mathrm{v}_{\mathrm{T}}+0.8\right)=\mathrm{a}_{1}+\mathrm{a}_{2} * \log (\mathrm{T}) \\
\mathrm{a}_{1}=5.489+0.148 *\left(\mathrm{~T}_{\mathrm{b}}\right)^{0.5} \\
\mathrm{a}_{2}=-3.7\end{array}$ & (4) \\
\hline Puttagunta et al. & $\begin{array}{c}\log \left(v_{T}\right)=B *\left(\frac{559.67}{T+459.67}\right)^{S}-0.86960 \\
B=\log \left(v_{37.8}\right)+0.86960 \\
S=0.28008 *\left[\log \left(v_{37.8}\right)\right]+1.8616\end{array}$ & $(5)$ \\
\hline Beg et al. & $\begin{array}{c}\nu=\mathrm{A} * \exp \left(\frac{\mathrm{B}}{\mathrm{T}}\right) \\
\mathrm{B}=\exp \left(5.471+0.00342 * \mathrm{~T}_{50}\right) \\
\mathrm{A}=-0.0339 * \text { API }{ }^{0.188}+0.241 * \mathrm{~T}_{50} / \mathrm{b}\end{array}$ & (6) \\
\hline Beg and Amin 1 & $\begin{array}{c}v=\mathrm{A} * \exp \left(\frac{\mathrm{B}}{\mathrm{T}}\right) \\
\mathrm{B}=-15.8342 * 10^{4}+374.357 * \mathrm{~T}_{50}-0.2123 * \mathrm{~T}_{50}{ }^{2} \\
\mathrm{~A}=62.542 * 10^{-7}+0.4274 * \exp \left(-15.06 * 10^{-4} * \mathrm{~B}\right)\end{array}$ & (7) \\
\hline
\end{tabular}




\begin{tabular}{|c|c|c|}
\hline Beg and Amin 2 & $\begin{array}{c}\nu=\mathrm{A} * \exp \left(\frac{\mathrm{B}}{\mathrm{T}}\right) \\
\mathrm{A}=-1.954 * 10^{-3}+0.0906 * \exp \left(-7.773 * 10^{-3} * \mathrm{M}\right) \\
\mathrm{B}=67.45+\exp \left(5.329+0.00329 * \mathrm{~T}_{50}\right)+44.263 *(\mathrm{M} / \mathrm{API})\end{array}$ & (8) \\
\hline Fang Lei & $\begin{array}{l}\ln \left(\mathrm{v}_{\mathrm{T}} / \mathrm{T}\right)=59.06 * \mathrm{~T}_{50 \%}{ }^{0.1546} * \mathrm{M}^{0.4791} * \rho_{\mathrm{T}} / \mathrm{T}-(18.103+\ln \mathrm{M}) \\
\quad \rho_{\mathrm{T}}=\left[\left(\rho_{15.6}{ }^{2}-1,1 * 10^{-3} *(\mathrm{~T}-15.6)\right)\right]^{0,5} \\
\mathrm{M}=219.05 * \operatorname{Exp}\left(0.003924 *\left(\mathrm{~T}_{50 \%}+273.15\right)\right) * \exp (-3.07 * \mathrm{~S}) \\
273.15)^{0.118} * \mathrm{~S}^{1.88} \\
\mathrm{~S}=\rho_{15.6} / 0.999024\end{array}$ & (9) \\
\hline ASTM D341 & $\begin{array}{c}\log (\log (\mathrm{Z}))=\mathrm{A}-\mathrm{B} \log (\mathrm{T}) \\
\mathrm{Z}=\mathrm{v}+0,7+\exp \left(-1.47-1.84 * \mathrm{v}-0.1 * \mathrm{v}^{2}\right) \\
\mathrm{v}=\mathrm{Z}-0.7-\exp \left(-0.7487-3295 *(\mathrm{Z}-0.7)+0.6119 *(\mathrm{Z}-0.7)^{2}\right. \\
-0.3193 *(\mathrm{Z}-0.7)^{3}\end{array}$ & $(10)$ \\
\hline Santos and Fregolente 1 & $v_{98.8^{\circ} \mathrm{C}}=\left(0.657 * v_{60^{\circ} \mathrm{C}}\right)^{\left(1.4263-0.00069699 * \mathrm{~d}_{20^{\circ} \mathrm{C}}\right)}$ & $(11)$ \\
\hline Santos and Fregolente 2 & $v_{98.8^{\circ} \mathrm{C}}=0.6392 * v_{60^{\circ} \mathrm{C}} 0.7561$ & (12) \\
\hline
\end{tabular}

\subsection{Prediction of kinematic viscosity of blends}

Kinematic viscosity of blends $\left(v_{m}\right)$ can be predicted by two types of methods, such as mixture-viscosity equations and parameter mixing rules [1]. Their application depends on component similarity.

\subsubsection{Mixture-viscosity equations}

One of the simplest approach to calculate some properties of mixtures is applying linear blending model and expressed by the weighted average of each blend component's property. The average can be based on volumetric, mole or mass fraction [45]. However, some properties, such as kinematic viscosity, cannot be expressed by linear blending but by other type of models [45]. Some empirical models for KV of mixtures $\left(v_{m}\right)$ were developed for mixtures consisting of nonpolar compounds and with similar structure [47] such as Chirinos [48] apud [37], Cragoe [49] apud [50], Arrhenius [51] apud [52], Bingham [53] apud [54], Linear [55], Kendal and Monroe [55], Refutas [56] apud [37], and Chevron [57] models (Table 2).

Based on mass fraction and $\mathrm{KV}$ of each component, the $\mathrm{KV}$ of a binary mixture can be predicted by Chirinos model (Eq.(13) [48] apud [37] and Cragoe method (Eq.(15) [49] apud [50]. However, for Cragoe model, two more parameters are required, $L_{i}$ (Cragoe parameter of each compound i) and L (Cragoe parameter), which are calculated through the KV of each compound i $\left(v_{i}\right)$ and mass fraction $\left(w_{i}\right)[58]$ apud $[49,50]$. 
Through volume fraction $\left(V_{i}\right)$, the $\mathrm{KV}$ of a binary mixture of hydrocarbons can be predicted by applying Arrhenius model [51] apud [52], Bingham model [53] apud [54], or Linear model [55], Eq. (14), Eq.(16), and Eq. (18) respectively.

For KV prediction of a binary mixture based on mole fraction, $x_{i}$, Kendal and Monroe model [55] (Eq. 17) can be applied. This model is recommended by API-TDB [45] and it is widely used due to its satisfactory results [1]. Arrhenius model and Kendal and Monroe model (Equations (14) and (17), respectively) produce accurate results if the chemical structure of the two compounds is similar, such as non-polar and non-associated liquid, and if one of the compound is predominant [47].

Finally, there are Refutas model [56] apud [37] and Chevron model [57] (Equations (19) and (20), respectively), which are different from the previous methods, since they are based on index mixture. Also, similarly to Bingham [53] apud [54], Arrhenius [51] apud [52], and Linear [55] models, they are calculated on volumetric fraction.

Table 2 - Models of Mixing of pure component viscosities

\begin{tabular}{c|c|c}
\hline Model & Equation & \# Eq. \\
\hline Chirinos & $\begin{array}{c}\log \left(\log \left(v_{\mathrm{m}}+0.7\right)\right. \\
=\left(\left(\mathrm{w}_{\mathrm{a}} * \log 10\left(\log 10\left(\mathrm{v}_{\mathrm{a}}+0.7\right)\right)\right)+\left(\mathrm{w}_{\mathrm{b}}\right.\right. \\
\left.\left.\left.* \log 10\left(\log 10\left(v_{\mathrm{b}}+0.7\right)\right)\right)\right)\right)\end{array}$ & $(13)$ \\
\hline Arrhenius & $v_{\mathrm{m}}=10^{\left(\sum \mathrm{v}_{\mathrm{i}} * \log \left(\mathrm{v}_{\mathrm{i}}\right)\right)}$ & $(14)$ \\
\hline Cragoe & $\mathrm{v}_{\mathrm{m}}=5 * 10^{-4} * \exp \left(1000 * \ln \left(\frac{20}{\mathrm{~L}}\right)\right)$ & $(15)$ \\
& $\mathrm{L}=\sum \mathrm{w}_{\mathrm{i}} * \mathrm{~L}_{\mathrm{i}}$ & \\
\hline Bingham & $\mathrm{L}_{\mathrm{i}}=1000 * \ln 20 /\left(\ln \mathrm{v}_{\mathrm{i}}-\ln \left(5 * 10^{-4}\right)\right.$ & $(16)$ \\
\hline Kendal and Monroe & $v_{\mathrm{m}}=1 / \sum\left(\mathrm{V}_{\mathrm{i}} * v_{\mathrm{i}}\right)$ & $(17)$ \\
\hline Linear & $v_{\mathrm{m}}=\left(\sum\left(\mathrm{x}_{\mathrm{i}} * v_{\mathrm{i}}\right)^{1 / 3}\right)^{3}$ & $(18)$ \\
\hline Refutas & $v_{\mathrm{m}}=\sum \mathrm{V}_{\mathrm{i}} * v_{\mathrm{i}}$ & $(19)$ \\
\hline Chevron & $\mathrm{VBI}_{\mathrm{I}}=10.975+14.534 * \ln \left(\ln \left(v_{\mathrm{i}}+0.8\right)\right)$ & $(20)$ \\
\hline
\end{tabular}




\subsubsection{Empirical models with additional parameters}

Equations (13) to (20) can predict the KV of blends $\left(v_{m}\right)$ composed by components with similar properties. Then, when this similarity decreases, the prediction deviation increases. Therefore, equations with additional parameters (Table 3) are more suitable for complex mixtures to obtain higher accuracy $[59,13]$.

Walther [37] model (Eq.(21)) requires a parameter C, which is obtained from regression analysis. This parameter is related to type of mixture, such as $\mathrm{C}=0.8$ for petroleum mixtures [37].

Lederer [60] (Eq.(22)) is an Arrhenius model modification that estimates KV through parameter alpha and the effective mole fraction, $x_{A}^{\prime}$. Alpha parameter is called degree of association and is calculated through experimental KV of the mixture [60]. According to the literature, Lederer [60] and Cragoe [49] apud [50] models provide a similar and satisfactory prediction for blend of petroleum fractions with low viscosity ratios [52]. In addition, Shu [61] developed a correlation to obtain alpha for heavy oil and petroleum fractions (Eq.(23)) [61].

Power model, a modification of Kendal and Monroe [23] model (Eq.(24)), and Miadonye et al. [36] model (Eq.(25) use mass fraction to predict KV. Miadonye et al. model has two parameters, related to viscosity interaction (a) and viscosity reduction (n). This model was developed to predict $\mathrm{KF}$ of bitumen $\left(v_{B}\right)$ and diluent blend $\left(v_{D}\right)$ [36].

As a recommendation of API-TDB, there is Twu Bulls [45] model to predict the KV of a binary mixture, requiring $\mathrm{KV}$ at two different temperatures ( $\mathrm{T}$, in degrees Rankine) to estimate $\mathrm{m}$ and $b$ parameters (Eq.(26).

Table 3 - Mixture models with additional parameters

\begin{tabular}{cc}
\hline Model & Equation
\end{tabular}




\begin{tabular}{cc}
\hline Model & Equation \\
\hline $\begin{array}{c}\text { Shu (alpha for } \\
\text { Lederer model) }\end{array}$ & $\alpha=\frac{17.04 *\left(\rho_{A}-\rho_{B}\right)^{0.5237} * \rho_{A}{ }^{3.2745} * \rho_{B}{ }^{1.6316}}{\ln \left(\mu_{\mathrm{A}} / \mu_{B}\right)}$ \\
Power & $v_{\mathrm{m}}=\left(\sum\left(\mathrm{w}_{\mathrm{i}} * \mathrm{visc}_{\mathrm{i}}\right)^{n}\right)^{1 / \mathrm{n}}$ \\
& $v_{\mathrm{m}}=\exp \left(\exp \left(\mathrm{a} *\left(1-w_{D}{ }^{n}\right)\right)+\ln v_{D}-1\right)$ \\
Miadonye et al. & $\mathrm{a}=\ln \left(\ln v_{B}-v_{D}+1\right)$ \\
& $\mathrm{n}=v_{D} /\left(0.9029 * v_{D}+0.1351\right)$ \\
$\ln \left(\ln \left(v_{\mathrm{m}}+0.7\right)\right)=\mathrm{m} *(\ln \mathrm{T})+\mathrm{b}$
\end{tabular}

\section{Methodology}

After reviewing predictive methods of KV (Table 1, Table 2, and Table 3), we calculated it applying, as input, some experimental properties provided by Brazilian oil industries and from the literature. Posteriorly, once $\mathrm{R}^{2}$ might be inappropriate to validate the performance of nonlinear models, we evaluated their performance by the average of absolute difference between the calculated property and the value of experimental property. We calculated average absolute deviation percentage, \%AAD (Eq. (27)), and average absolute deviation, AAD (Eq.(28)). As a result, comparing the $\% \mathrm{AAD}$ of each predictive method, the most appropriate and accurate one is the equation that provided predicted $\mathrm{KV}$ with the minor \% AAD.

$$
\begin{gathered}
\% A A D=\frac{100 * 1}{N} \sum_{i=1}^{N}\left|\frac{v_{\text {calculated }, i}-v_{\text {experimental }, i}}{v_{\text {experimental }, i}}\right| \\
A A D=\frac{1}{N} \sum_{i=1}^{N}\left|v_{\text {calculated }, i}-v_{\text {experimental }, i}\right|
\end{gathered}
$$

\subsection{Approach for $\mathrm{KV}$ prediction of Diesel fraction from petroleum assays}

To predict KV of diesel fraction, we applied data (56 samples) from petroleum assays. The characterization of the petroleum can be represented by the specific range of values for some properties, such as specific gravity at $15^{\circ} \mathrm{C}$ from 0.82 to 0.91 , ${ }^{\circ} \mathrm{API}$ from 24.15 to $41.83, \mathrm{KV}$ at $20^{\circ} \mathrm{C}$ from $3.82 \mathrm{~mm}^{2} / \mathrm{s}$ to $15.23 \mathrm{~mm}^{2} / \mathrm{s}, \mathrm{KV}$ at $40^{\circ} \mathrm{C}$ from $2.59 \mathrm{~mm}^{2} / \mathrm{s}$ to $7.83 \mathrm{~mm}^{2} / \mathrm{s}, \mathrm{KV}$ at $50^{\circ} \mathrm{C}$ 
from $2.20 \mathrm{~mm}^{2} / \mathrm{s}$ to $5.97 \mathrm{~mm}^{2} / \mathrm{s}, \mathrm{KV}$ at $100^{\circ} \mathrm{C}$ from $1.18 \mathrm{~mm}^{2} / \mathrm{s}$ to $2.26 \mathrm{~mm}^{2} / \mathrm{s}$, and $\mathrm{KV}$ at $150^{\circ} \mathrm{C}$ from $0.76 \mathrm{~mm}^{2} / \mathrm{s}$ to $1.24 \mathrm{~mm}^{2} / \mathrm{s}$ (Table 4) [62].

Table 4 - Properties of experimental data of diesel fraction from petroleum assays

\begin{tabular}{llll}
\hline Properties & Minimum value & Maximum value & Average value \\
\hline Specific gravity at $15^{\circ} \mathrm{C}$ & 0.82 & 0.91 & 0.86 \\
${ }^{\circ}$ API & 24.15 & 41.83 & 32.87 \\
Kinematic viscosity @ $20^{\circ} \mathrm{C}\left(\mathrm{mm}^{2} / \mathrm{s}\right)$ & 3.82 & 15.23 & 7.29 \\
Kinematic viscosity @ $40^{\circ} \mathrm{C}\left(\mathrm{mm}^{2} / \mathrm{s}\right)$ & 2.59 & 7.83 & 4.22 \\
Kinematic viscosity @ $50{ }^{\circ} \mathrm{C}\left(\mathrm{mm}^{2} / \mathrm{s}\right)$ & 2.20 & 5.97 & 3.37 \\
Kinematic viscosity @ $100^{\circ} \mathrm{C}\left(\mathrm{mm}^{2} / \mathrm{s}\right)$ & 1.18 & 2.26 & 1.50 \\
Kinematic viscosity @ $150^{\circ} \mathrm{C}\left(\mathrm{mm}^{2} / \mathrm{s}\right)$ & 0.76 & 1.24 & 0.89 \\
\hline
\end{tabular}

We also calculated $\mathrm{KV}$ at several temperatures for diesel fraction, applying methods developed to obtain KV through KV data at different temperatures (Eq.5 and Eq.10) (Table 5). As mentioned previously, methods requiring $\mathrm{KV}$ at specific temperature to obtain $\mathrm{KV}$ in a different temperature are not considered predictive but a conversion one.

Table 5 - Input Properties applied to calculate KV at T temperature

\begin{tabular}{|c|c|c|}
\hline Model & Target Calculation: $\mathrm{KV}$ at $\mathrm{T}$ & Properties as Input \\
\hline Eq.(5) & $\mathrm{KV}$ at $40^{\circ} \mathrm{C}$ & $\begin{array}{l}\mathrm{KV} \text { data at } 20^{\circ} \mathrm{C}, 50^{\circ} \mathrm{C}, 100^{\circ} \mathrm{C} \text { and } 150^{\circ} \mathrm{C} \\
\text { Three different systems: }\end{array}$ \\
\hline Eq.(10) & $\mathrm{KV}$ at $100{ }^{\circ} \mathrm{C}$ & $\begin{array}{l}\mathrm{KV} \text { at } 40^{\circ} \mathrm{C} \text { and } 20^{\circ} \mathrm{C}, 40{ }^{\circ} \mathrm{C} \text { and } 50^{\circ} \mathrm{C} \text {, and } 50^{\circ} \mathrm{C} \\
\text { and } 100^{\circ} \mathrm{C} \\
\text { Three different systems }\end{array}$ \\
\hline Eq.(10) & $\mathrm{KV}$ at $20^{\circ} \mathrm{C}$ & $\begin{array}{l}\mathrm{KV} \text { at } 40{ }^{\circ} \mathrm{C} \text { and } 50^{\circ} \mathrm{C}, 100{ }^{\circ} \mathrm{C} \text { and } 150^{\circ} \mathrm{C} \text {, and } 40 \\
{ }^{\circ} \mathrm{C} \text { and } 150^{\circ} \mathrm{C} \\
\text { Three different systems }\end{array}$ \\
\hline Eq.(10) & $\mathrm{KV}$ at $50^{\circ} \mathrm{C}$ & $\begin{array}{l}\mathrm{KV} \text { at } 40{ }^{\circ} \mathrm{C} \text { and } 50{ }^{\circ} \mathrm{C}, 40{ }^{\circ} \mathrm{C} \text { and } 150{ }^{\circ} \mathrm{C} \text {, and } \\
100^{\circ} \mathrm{C} \text { and } 150{ }^{\circ} \mathrm{C} \\
\text { Three different systems }\end{array}$ \\
\hline Eq.(10) & $\mathrm{KV}$ at $40^{\circ} \mathrm{C}$ & $\begin{array}{l}\mathrm{KV} \text { at } 20^{\circ} \mathrm{C} \text { and } 50{ }^{\circ} \mathrm{C}, 20^{\circ} \mathrm{C} \text { and } 150{ }^{\circ} \mathrm{C} \text {, and } \\
100^{\circ} \mathrm{C} \text { and } 150{ }^{\circ} \mathrm{C} \\
\text { Three different systems }\end{array}$ \\
\hline Eq.(10) & $\mathrm{KV}$ at $150^{\circ} \mathrm{C}$ & $\begin{array}{l}\mathrm{KV} \text { at } 40^{\circ} \mathrm{C} \text { and } 20^{\circ} \mathrm{C}, 40^{\circ} \mathrm{C} \text { and } 50^{\circ} \mathrm{C} \text {, and } 100^{\circ} \mathrm{C} \\
\text { and } 50^{\circ} \mathrm{C}\end{array}$ \\
\hline
\end{tabular}

To estimate KV by Eq.(8), it was necessary to calculate molecular weight, since this is a difficult property to acquire, through mean average boiling point of petroleum fraction $\left({ }^{\circ} \mathrm{R}\right), T_{b}$, 
and specific gravity at $60^{\circ} \mathrm{F} / 60^{\circ} \mathrm{F}$, s. The method for molar mass prediction (Eq.(29) is applicable for a boiling point from $90^{\circ} \mathrm{F}$ to $1050{ }^{\circ} \mathrm{F}$, API gravity from 14.4 to 93.1 , and specific gravity from 0.63 to 0.97 , and it is recommended by API-TDB [45].

$$
\begin{aligned}
M=20.486 * & \left(e^{1.165 * 10^{-4} * T b-7,78712 * d_{60 F / 60 F}+1.1582 * 10^{-3} * T b * d_{60 F / 60 F}}\right) * T b^{1,26007} \\
& * d_{60 F / 60 F} 4,98308
\end{aligned}
$$

\subsection{Approach for $\mathrm{KV}$ prediction of Diesel fraction $\mathrm{S500}$ from blending systems}

To evaluate KV prediction methods, we applied 95 data of diesel S500 from blending system from Brazilian oil industries, which has specific properties (Table 6). All the models presented previously were evaluated, except Eq.(11) and Eq.(12), once they have been developed for heavy oil, as well as Eq.(7), designated for heavy petroleum fraction.

Table 6 - Properties of experimental data of diesel S500

\begin{tabular}{llll}
\hline Properties & Minimum value & Maximum value & Average value \\
\hline Density at $20^{\circ} \mathrm{C}\left(\mathrm{kg} / \mathrm{m}^{3}\right)$ & 827.10 & 862.90 & 845.13 \\
Kinematic viscosity @ $40{ }^{\circ} \mathrm{C}\left(\mathrm{mm}^{2} / \mathrm{s}\right)$ & 2.30 & 4.20 & 3.11 \\
Temperature at $30 \%$ volume distilled $\left(T_{30}\right.$ & 120.60 & 216.90 & 186.97 \\
$\left.\left({ }^{\circ} \mathrm{C}\right)\right)$ & & & \\
Flash Point $\left({ }^{\circ} \mathrm{C}\right)$ & 39 & 72 & 47.39 \\
\hline
\end{tabular}

\subsection{Approach for improving $K V$ prediction of diesel fractions}

To obtain higher accuracy, we applied diesel data from petroleum assays to develop new models at temperatures from $20{ }^{\circ} \mathrm{C}$ to $150{ }^{\circ} \mathrm{C}$ and also a new method to predict $\mathrm{KV}$ at any temperature. In addition, since $40^{\circ} \mathrm{C}$ is a crucial temperature to monitor kinematic viscosity for diesel specifications, we combined diesel fraction data from assays and diesel S500 from blending system to generate a model to amplify the restriction range for $\mathrm{KV}$ prediction at $40{ }^{\circ} \mathrm{C}$.

Lastly, new methods were tested and validated with different data. Those new equations that predict $\mathrm{KV}$ at any temperature and $\mathrm{KV}$ at $40{ }^{\circ} \mathrm{C}$ were also evaluated through diesel S500 data to compare results from existing models. 


\subsection{Approach for $K V$ prediction of diesel-biodiesel blends: effect of temperature, volume fraction, and biodiesel feedstock at $\mathrm{KV}$ prediction}

To evaluate the accuracy of predictive methods (models with additional parameters and models for mixing pure component viscosities) of KV and their application for mixtures of fossil fuel and renewable fuel, such as biodiesel, diesel and biodiesel, 431 data from literature were applied. Those data comprehend density and KV at several temperatures, such as at $20^{\circ} \mathrm{C}, 30^{\circ} \mathrm{C}$, $40^{\circ} \mathrm{C}, 60^{\circ} \mathrm{C}, 80^{\circ} \mathrm{C}$, and $100{ }^{\circ} \mathrm{C}$ (Table 7). In addition, we applied data with varied volume fraction of diesel and data with several types of feedstock of biodiesel, such as soybean, yellow grass, castor, peanut, sunflower, canola, etc. (Table 8). For this study, all the methods were evaluated, except Shu (Eq.23), once it requires non available data such as density of each compound at specific temperature.

Table 7 - Average of KV at temperature $\mathrm{T}$

\begin{tabular}{|c|c|c|c|c|c|c|c|}
\hline \multirow{2}{*}{ Biodiesel type } & \multicolumn{5}{|c|}{ Average $\mathrm{KV}\left(\mathrm{mm}^{2} / \mathrm{s}\right)$ at temperature $\mathrm{T}\left({ }^{\circ} \mathrm{C}\right)$} & \multicolumn{2}{|r|}{ Ref } \\
\hline & $\mathbf{T}=\mathbf{2 0 . 0 0}{ }^{\circ} \mathbf{C}$ & $\mathbf{T}=\mathbf{3 0}{ }^{\circ} \mathbf{C}$ & $\mathrm{T}=\mathbf{4 0 . 0 0}{ }^{\circ} \mathrm{C}$ & $\mathrm{T}=6 \mathbf{6 0 . 0 0}{ }^{\circ} \mathrm{C}$ & $\mathrm{T}=\mathbf{8 0 . 0 0}{ }^{\circ} \mathrm{C}$ & $\mathrm{T}=\mathbf{1 0 0 . 0 0}^{\circ} \mathrm{C}$ & \\
\hline Canola FAME & - & - & 4.34 & - & 2.09 & - & [40]; [4] \\
\hline Castor FAME & - & - & 14.77 & - & - & - & [63] \\
\hline Coconut FAME & - & 6.15 & - & - & 1.41 & - & [40]; [9] \\
\hline Corn FAME & - & - & 4.35 & - & - & - & [4]; [64]; [42] \\
\hline Cottonseed FAME & - & - & 4.06 & - & 2.01 & - & {$[40] ;[4]$} \\
\hline Diesel & 3.94 & - & 3.5 & 1.82 & 1.37 & 1.09 & $\begin{array}{l}\text { [40]; [65]; [64]; } \\
{[63] ;[42] ;[9][66]}\end{array}$ \\
\hline Jatropha FAME & - & 6.44 & 4.48 & - & - & - & {$[42] ;[9]$} \\
\hline Palm FAME & - & - & 4.65 & - & 2.08 & - & [40]; [63] \\
\hline Peanut FAME & - & - & - & - & 2.11 & - & {$[40]$} \\
\hline Pomace FAME & - & - & 4.79 & - & - & - & {$[42]$} \\
\hline Rapeseed FAME & - & - & 5.48 & - & 2.58 & - & [40]; [64] \\
\hline Sesame FAME & - & - & 4.59 & - & - & - & {$[42]$} \\
\hline Soybean FAME & 7.16 & - & 4.16 & 3.08 & 2.25 & 1.77 & $\begin{array}{l}\text { [40]; [65]; [4]; [42]; } \\
{[66]}\end{array}$ \\
\hline Soybean FAEE & - & - & 5.83 & - & - & - & {$[65]$} \\
\hline Sunflower FAME & - & - & 4.16 & - & - & - & [4]; [42] \\
\hline Waste FAME & - & 6.76 & 4.75 & - & - & - & [4]; [64]; [9] \\
\hline Yellow Grease FAME & 8.34 & - & 5.02 & 3.36 & 2.42 & 1.86 & [42]; [66] \\
\hline
\end{tabular}


Table 8 - Diesel-biodiesel systems (several volume fractions and types of biodiesel) to evaluate $\mathrm{KV}$ prediction of mixtures

\begin{tabular}{lll}
\hline Blend system & \%volume fraction of biodiesel & Ref \\
\hline Diesel+ palm oil FAME & $20 ; 40 ; 60 ; 80$ & {$[40],[63]$} \\
Diesel+ peanut oil FAME & $5 ; 20$ & {$[40]$} \\
Diesel+ waste oil FAME & $2 ; 5 ; 10 ; 20 ; 50 ; 75$ & {$[4],[64],[9]$} \\
Diesel+ sunflower oil FAME & $2 ; 5 ; 10 ; 20 ; 50 ; 75$ & {$[4],[42]$} \\
Diesel+ canola oil FAME & $2 ; 5 ; 10 ; 20 ; 50 ; 75$ & {$[40],[4]$} \\
Diesel+ yellow grease FAME & $25 ; 20 ; 75$ & {$[66]$} \\
Diesel+ coconut oil FAME & $5 ; 10 ; 20 ; 40 ; 50 ; 60 ; 75$ & {$[40],[9]$} \\
Diesel+ castor oil FAME & $20 ; 40 ; 60 ; 80$ & {$[63]$} \\
Diesel+ jatropha oil FAME & $2 ; 5 ; 10 ; 20 ; 50 ; 75$ & {$[42],[9]$} \\
Diesel+ corn oil FAME & $2 ; 5 ; 10 ; 20 ; 50 ; 75$ & {$[4],[64],[42]$} \\
Diesel+ cottonseed oil FAME & $10 ; 20$ & {$[4],[40]$} \\
Diesel+ rapeseed oil FAME & $5 ; 20$ & {$[64]$} \\
Diesel+ sesame oil FAME & $2 ; 5 ; 10 ; 20 ; 50 ; 75$ & {$[42]$} \\
Diesel+ pomace oil FAME & $2 ; 5 ; 10 ; 20 ; 50 ; 75$ & {$[42]$} \\
Diesel+ soybean oil FAME & $2 ; 5 ; 10 ; 15 ; 20 ; 25 ; 50 ; 75$ & {$[4],[66],[42]$} \\
Diesel+ soybean oil FAEE & $5 ; 15 ; 20 ; 25 ; 50$ & {$[65]$} \\
\hline
\end{tabular}

\section{Results and Discussion}

\subsection{Diesel fraction from petroleum assays}

\subsubsection{Evaluating empirical models of $K V$}

For KV calculation of diesel fraction from petroleum assays, we observed that the best accuracy was from Eq.(10), with deviation around zero for $\mathrm{KV}$ at temperatures from $20{ }^{\circ} \mathrm{C}$ to 50 ${ }^{\circ} \mathrm{C}$. Differently, the deviation from Eq.(10) was not zero for $\mathrm{KV}$ at $100^{\circ} \mathrm{C}(\% \mathrm{AAD}=0.45)$ nor $\mathrm{KV}$ at $150^{\circ} \mathrm{C}(\% \mathrm{AAD}=3.55)$. As a result from this evaluation, we observed that Eq.(10), independently of $\mathrm{KV}$ at a specific temperature, presented higher accuracy. However, we highlight that this is not a predictive model, since it requires two kinematic viscosities in different temperatures to obtain $\mathrm{KV}$ in another temperature, as well as Eq.(5). Therefore, if there are available KV in two different temperatures, we recommend applying Eq.(10) to obtain KV at the desired temperature. Otherwise, one must apply a predictive method.

For that, evaluating several methods shown at Table 1, we obtained different behavior and results for each model, according to specific temperature (Table 9). In another words, even though 
all models can be applied for any temperature, we identified accuracy variation according to the temperature of kinematic viscosity.

Prediction of kinematic viscosity at $150{ }^{\circ} \mathrm{C}$ was more accurate if obtained through Eq.(6) with minor deviation $\left(\mathrm{AAD}=0.04 \mathrm{~mm}^{2} / \mathrm{s}\right.$ and $\left.\% \mathrm{AAD}=4.70\right)$. For Kinematic viscosity at $100{ }^{\circ} \mathrm{C}$, the most accurate model was obtained from Eq.(6) (AAD $=0.06 \mathrm{~mm}^{2} / \mathrm{s}$ and $\left.\% \mathrm{AAD}=4.07\right)$. At $50{ }^{\circ} \mathrm{C}$, kinematic viscosity prediction was more accurate applying Eq.(3) (AAD $=0.29 \mathrm{~mm}^{2} / \mathrm{s}$ and $\% \mathrm{AAD}=8.96$ ). Eq.(3), Eq.(4), and Eq.(6) presented the highest deviation. At $40{ }^{\circ} \mathrm{C}$, the most accurate model to predict $\mathrm{KV}$ was Eq.(3) $\left(\mathrm{AAD}=0.41 \mathrm{~mm}^{2} / \mathrm{s}\right.$ and $\left.\% \mathrm{AAD}=10.21\right)$. Finally, at $20^{\circ} \mathrm{C}$, the most accurate model to predict $\mathrm{KV}$ was $\mathrm{Eq} .(3)\left(\mathrm{AAD}=0.41 \mathrm{~mm}^{2} / \mathrm{s}\right.$ and $\left.\% \mathrm{AAD}=10.21\right)$.

Therefore, we assumed that $\mathrm{KV}$ prediction can be performed by specific equations depending on the temperature range. For example, at $150{ }^{\circ} \mathrm{C}$ and $100{ }^{\circ} \mathrm{C}, \mathrm{KV}$ presents the same performance. Then, KV can be predicted by the same model, which is Eq.(6). For lower temperatures, such as $50^{\circ} \mathrm{C}, 40{ }^{\circ} \mathrm{C}$, and $20{ }^{\circ} \mathrm{C}$, Eq.(3) is the most appropriate model.

By this assessment of predictive methods, we realized that two input properties, such as mid boiling point and specific gravity or API gravity, are recommended to predict flow liquid behavior at temperatures from 20 to $150^{\circ} \mathrm{C}$. Perhaps, because of that, Eq.(4) presented higher deviation, since it requires only mid-boiling point.

Table 9 - Results from KV $\left(\mathrm{mm}^{2} / \mathrm{s}\right)$ through predictive models for diesel fraction at specific temperature $\mathrm{T}\left({ }^{\circ} \mathrm{C}\right)$ by applying $\mathrm{T} 30$ and specific gravity

\begin{tabular}{|c|c|c|c|c|c|c|c|c|c|c|c|}
\hline $\begin{array}{l}\mathbf{K V} \\
@ \mathbf{T}\end{array}$ & Model & AAD & \% AAD & $\begin{array}{l}\mathbf{K V} \\
@ \mathbf{T}\end{array}$ & Model & AAD & $\%$ AAD & $\begin{array}{l}\mathbf{K V} \\
@ \mathbf{T}\end{array}$ & Model & AAD & $\% \mathrm{AAD}$ \\
\hline \multirow{6}{*}{$150^{\circ} \mathrm{C}$} & Eq.(6) & 0.04 & 4.70 & \multirow{6}{*}{$100^{\circ} \mathrm{C}$} & Eq.(6) & 0.06 & 4.07 & & & & \\
\hline & Eq.(3) & 0.05 & 5.26 & & Eq.(9) & 0.08 & 5.23 & & & & \\
\hline & Eq.(5) & 0.05 & 5.59 & & Eq.(3) & 0.09 & 6.25 & & & & \\
\hline & Eq.(9) & 0.05 & 5.98 & & Eq.(8) & 0.14 & 9.65 & & & & \\
\hline & Eq.(8) & 0.10 & 11.34 & & Eq.(5) & 0.13 & 9.85 & & & & \\
\hline & Eq.(4) & 1.08 & 123.07 & & Eq.(4) & 1.18 & 80.68 & & & & \\
\hline \multirow{6}{*}{$50^{\circ} \mathrm{C}$} & Eq.(3) & 0.29 & 8.96 & \multirow{6}{*}{$40^{\circ} \mathrm{C}$} & Eq.(3) & 0.41 & 10.21 & \multirow{6}{*}{$20^{\circ} \mathrm{C}$} & Eq.(3) & 0.84 & 13.14 \\
\hline & Eq.(6) & 0.39 & 11.51 & & Eq.(4) & 0.51 & 13.33 & & Eq.(5) & 0.78 & 14.73 \\
\hline & Eq.(9) & 0.42 & 12.90 & & Eq.(6) & 0.66 & 15.68 & & Eq.(4) & 1.10 & 16.40 \\
\hline & Eq.(8) & 0.54 & 16.64 & & Eq.(9) & 0.69 & 16.78 & & Eq.(6) & 1.69 & 25.69 \\
\hline & Eq.(5) & 0.48 & 17.64 & & \multirow{2}{*}{ Eq.(8) } & \multirow{2}{*}{0.83} & \multirow{2}{*}{20.48} & & Eq.(9) & 1.70 & 26.19 \\
\hline & Eq.(4) & 0.71 & 23.30 & & & & & & Eq.(8) & 1.98 & 30.47 \\
\hline
\end{tabular}


Assembling the results of $\mathrm{KV}$ predicted at several temperatures $\left(20^{\circ} \mathrm{C}\right.$ to $\left.150{ }^{\circ} \mathrm{C}\right)$, except results from Eq.(5), which did not predict $\mathrm{KV}$ at $\mathrm{T}=37.8^{\circ} \mathrm{C}$ once it is an input of the equation, we obtained that Eq.(6) was the most accurate method to predict $\mathrm{KV}$ at any temperature, since it presented minor deviation $\left(\mathrm{AAD}=0.328 \mathrm{~mm}^{2} / \mathrm{s}\right.$ and $\left.\% \mathrm{AAD}=8.22\right)($ Table 10$)$.

Table 10 - Results from KV prediction at any temperature T

\begin{tabular}{ccc}
\hline Model & $\begin{array}{c}\text { AAD } \\
\left(\mathbf{m m}^{2} / \mathbf{s}\right)\end{array}$ & \%AAD \\
\hline Eq.(6) & 0.33 & 8.22 \\
Eq.(3) & 0.36 & 10.01 \\
Eq.(5) & 0.42 & 10.29 \\
Eq.(9) & 0.62 & 14.73 \\
Eq.(8) & 0.62 & 16.36 \\
Eq.(4) & 1.16 & 55.6 \\
\hline
\end{tabular}

Once diesel fractions data have presented $\mathrm{K}_{\mathrm{API}}$ from 12.56 to 13.86 , Eq. (1) and Eq. (2) were not applicable in this study. In addition, we did not evaluate Eq.(11) and Eq. (12), since they have been developed for heavy oils. The Eq.(7) also was not evaluated because it is designated for heavy petroleum fraction.

\subsection{Diesel fractions $\mathbf{S 5 0 0}$ from blending systems}

\subsubsection{Evaluating empirical models}

Applying existing models to predict KV of diesel fraction S500 from blending systems at $40{ }^{\circ} \mathrm{C}$, we observed that Eq.(3) presented a satisfactory accuracy (\% AAD = 6.69) (Table 11). Comparing this result with $\mathrm{KV}$ prediction at $40{ }^{\circ} \mathrm{C}$ from diesel fraction from petroleum assays, we observed that Eq.(3) is the most appropriate existing model to predict diesel fraction $\mathrm{KV}$ at $40{ }^{\circ} \mathrm{C}$.

Eq. (7), Eq. (11), and Eq. (12) were not evaluated, since they are not applicable for KV data of diesel S500, but for heavier fractions. Also, Eq.(5) was not evaluated once it requires KV at 37.8 ${ }^{\circ} \mathrm{C}$. 
Eq.(1) is originally developed to predict $\mathrm{KV}$ at $37.8^{\circ} \mathrm{C}$, not $40{ }^{\circ} \mathrm{C}$. However, it presented the second minor deviation (\%AAD = 7.52). Therefore, Eq.(1) can also be applied to predict KV at $40{ }^{\circ} \mathrm{C}$ with accuracy similar to Eq.(3).

Table 11 - Results from existing models evaluation for $\mathrm{KV}$ at $40^{\circ} \mathrm{C}$

\begin{tabular}{ccr}
\hline Model & AAD $\left(\mathbf{m m}^{2} / \mathbf{s}\right)$ & \%AAD \\
\hline Eq.(3) & 0.21 & 6.69 \\
Eq.(1) & 0.23 & 7.52 \\
Eq.(9) & 0.34 & 10.93 \\
Eq.(6) & 0.35 & 11.12 \\
Eq.(8) & 0.44 & 14.07 \\
Eq.(4) & 0.88 & 28.12 \\
\hline
\end{tabular}

\subsection{Improving $K V$ prediction of diesel fractions: Developing new models}

Several equations for KV prediction from the literature presented low deviation, mainly at $150{ }^{\circ} \mathrm{C}$ and $100{ }^{\circ} \mathrm{C}$. However, to achieve higher accuracy, we developed new equations for several temperatures, such as $20{ }^{\circ} \mathrm{C}, 40{ }^{\circ} \mathrm{C}, 50{ }^{\circ} \mathrm{C}, 100{ }^{\circ} \mathrm{C}$, and $150{ }^{\circ} \mathrm{C}$, and also for any temperature $\mathrm{T}$ (Table 12 and Fig. 1 to Fig. 12) for diesel fractions.

We analyzed the linear and nonlinear correlation among kinematic viscosity and properties, such as T10, T30, T50 (temperature at 10, 30 and 50 vol\% distilled, respectively) and specific gravity to choose efficient parameters to predict KV. After calculations, T30 and specific gravity presented the most satisfactory performance through a nonlinear regression.

A new equation can predict $\mathrm{KV}$ at any temperature for diesel fraction (Eq.(35)) and it also presented lower deviation than the one from the existing models. In addition, we developed empirical methods to predict KV at specific temperature to improve accuracy (Eq. (30) to Eq. (34)). Those equations presented a deviation lower than $6 \%$ (Eq. (30) to Eq. (35)).

For $\mathrm{KV}$ at $40^{\circ} \mathrm{C}$, we developed a new method including diesel fraction data from petroleum assays and diesel fraction S500 data from blending system. Therefore, Eq.(31) can be applied for a larger range of diesel fraction data, such as $\mathrm{KV}$ from $0.81 \mathrm{~mm}^{2} / \mathrm{s}$ to $7.98 \mathrm{~mm}^{2} / \mathrm{s}, \mathrm{T}_{30 \%}$ from $214.00^{\circ} \mathrm{C}$ to $280.91{ }^{\circ} \mathrm{C}$, and specific gravity from 0.83 to 0.90 . 
We also tested those new equations with different data (testing data), which presented similar performance compared to training data, original data applied for developing new methods with adjusted coefficients (Table 12 and Fig. 1 to Fig. 12).

For KV prediction at any temperature, comparing results from the most accurate existing method (Eq.(6) with \%AAD = 8.22 (Table 10)), we observed that the developed method (Eq.(35)) presented higher accuracy, since its deviation was lower, \%AAD = 5.50 (Table 12).

For $\mathrm{KV}$ prediction at $40^{\circ} \mathrm{C}$, applying diesel S500 data from blending system, we also observed a satisfactory prediction. As a result, Eq.(35) presented deviation $A A D=0.11 \mathrm{~mm}^{2} / \mathrm{s}$ and $\% \mathrm{AAD}=4.00$, showing higher accuracy than the existing models.

The same occurred when we applied diesel S500 data to evaluate Eq.(31), which presented $\mathrm{AAD}=0.10 \mathrm{~mm}^{2} / \mathrm{s}$ and $\% \mathrm{AAD}=3.66$. Therefore, with similar performance (Fig. 13 and Fig. 14), to achieve higher accuracy from data similar to diesel S500, Eq.(35), and, mainly, Eq.(31), might be more efficient models to predict $\mathrm{KV}$ at $40{ }^{\circ} \mathrm{C}$.

We also observed that the test achieved minor deviation compared to the original data. This performance can be explained due to obedience to restriction ranges of these new models. 
Table 12 - New predictive KV models through T30 and specific gravity

\begin{tabular}{|c|c|c|c|c|c|c|c|c|}
\hline $\begin{array}{c}\mathrm{T} \\
\left({ }^{\circ} \mathrm{C}\right)\end{array}$ & Range & Method & Figure & $\begin{array}{l}\text { AAD } \\
\text { Regression } \\
\left(\mathrm{mm}^{2} / \mathrm{s}\right)\end{array}$ & $\begin{array}{l}\% \text { AAD } \\
\text { Regression }\end{array}$ & $\begin{array}{l}\text { AAD } \\
\text { Test } \\
\left(\mathrm{mm}^{2} / \mathrm{s}\right)\end{array}$ & $\begin{array}{l}\% \text { AAD } \\
\text { Test }\end{array}$ & Eq.\# \\
\hline 20 & $\begin{array}{l}\text { *For Regression (42 data) } \\
\mathrm{KV} \text { from } 5.01 \mathrm{~mm}^{2} / \mathrm{s} \text { to } 10.11 \mathrm{~mm}^{2} / \mathrm{s} \text {; T30 from } 266.08^{\circ} \mathrm{C} \text { to } \\
280.83{ }^{\circ} \mathrm{C} \text {; Specific gravity from } 0.83 \text { to } 0.89 \\
{ }^{*} \text { For Test ( } 10 \text { data) } \\
\mathrm{KV} \text { from } 5.94 \mathrm{~mm}^{2} / \mathrm{s} \text { to } 9.62 \mathrm{~mm}^{2} / \mathrm{s} \text {; from } 272.45^{\circ} \mathrm{C} \text { to } 280.91 \\
{ }^{\circ} \mathrm{C} \text {; }{ }^{\circ} \text { Specific gravity from } 0.84 \text { to } 0.90\end{array}$ & $\begin{array}{l}v_{20} \\
=\frac{0.6832 * \mathrm{~d}_{15} * 1.1358 * \mathrm{~T}_{30 \%}}{(0.2599 * \mathrm{~T})^{0.8905 * \mathrm{~d}_{15}}} \\
-5.0719 * \mathrm{~T}^{0.2000 /(0.0006 * \mathrm{~T} 30)}\end{array}$ & Fig. 1 & 0.39 & 5.58 & 0.37 & 4.76 & (30) \\
\hline 40 & $\begin{array}{l}\text { *For Regression (42 data) } \\
\mathrm{KV} \text { from } 2.40 \mathrm{~mm}^{2} / \mathrm{s} \text { to } 5.37 \mathrm{~mm}^{2} / \mathrm{s} \text {; T30 from } 214.00^{\circ} \mathrm{C} \text { to } \\
280.91{ }^{\circ} \mathrm{C} \text {; Specific gravity from } 0.83 \text { to } 0.90 \\
{ }^{*} \text { For Test ( } 10 \text { data) } \\
\mathrm{KV} \text { from } 2.50 \mathrm{~mm}^{2} / \mathrm{s} \text { to } 4.90 \mathrm{~mm}^{2} / \mathrm{s} \text {; from } 212.00^{\circ} \mathrm{C} \text { to } 280.77 \\
{ }^{\circ} \mathrm{C} ;{ }^{\circ} \text { Specific gravity from } 0.83 \text { to } 0.88\end{array}$ & $\begin{array}{l}v_{40} \\
=\frac{1.1161 * \mathrm{~d}_{15} * 1.4200 * \mathrm{~T}_{30 \%}}{(1.0014 * \mathrm{~T})^{0.8688 * \mathrm{~d}_{15}}} \\
-6.2297 * \mathrm{~T}^{0.0100 /(0.0030 * \mathrm{~T} 30)}\end{array}$ & Fig. 3 & 0.20 & 5.00 & 0.16 & 4.39 & (31) \\
\hline 50 & $\begin{array}{l}\text { *For Regression (42 data) } \\
\mathrm{KV} \text { from } 2.65 \mathrm{~mm}^{2} / \mathrm{s} \text { to } 4.16 \mathrm{~mm}^{2} / \mathrm{s} \text {; } \mathrm{T} 30 \text { from } 266.08^{\circ} \mathrm{C} \text { to } \\
280.83{ }^{\circ} \mathrm{C} \text {; Specific gravity from } 0.83 \text { to } 0.89 \\
{ }^{*} \text { For Test ( } 10 \text { data) } \\
\mathrm{KV} \text { from } 1.42 \mathrm{~mm}^{2} / \mathrm{s} \text { to } 1.73 \mathrm{~mm}^{2} / \mathrm{s} \text {; from } 272.45^{\circ} \mathrm{C} \text { to } 279.69 \\
{ }^{\circ} \mathrm{C} \text {; }{ }^{\circ} \text { Specific gravity from } 0.85 \text { to } 0.88\end{array}$ & $\begin{array}{l}v_{50} \\
=\frac{1.0171 * \mathrm{~d}_{15} * 1.2466 * \mathrm{~T}_{30 \%}}{(0.7935 * \mathrm{~T})^{0.9918 * \mathrm{~d}_{15}}} \\
-(6.0771 * \mathrm{~T})^{0.0022 /(0.0016 * \mathrm{~T} 30)}\end{array}$ & Fig. 5 & 0.15 & 4.57 & 0.08 & 2.37 & (32) \\
\hline 100 & $\begin{array}{l}{ }^{*} \text { For Regression (42 data) } \\
\mathrm{KV} \text { from } 1.42 \mathrm{~mm}^{2} / \mathrm{s} \text { to } 1.73 \mathrm{~mm}^{2} / \mathrm{s} \text {; T30 from } 266.08^{\circ} \mathrm{C} \text { to } \\
280.83{ }^{\circ} \mathrm{C} \text {; Specific gravity from } 0.83 \text { to } 0.89 \\
{ }^{*} \text { For Test ( } 10 \text { data) } \\
\mathrm{KV} \text { from } 1.42 \mathrm{~mm}^{2} / \mathrm{s} \text { to } 1.73 \mathrm{~mm}^{2} / \mathrm{s} \text {; from } 275.36^{\circ} \mathrm{C} \text { to } 280.91 \\
{ }^{\circ} \mathrm{C} \text {; }{ }^{\circ} \text { Specific gravity from } 0.84 \text { to } 0.90\end{array}$ & $\begin{array}{l}v_{100} \\
=\frac{1.6576 * \mathrm{~d}_{15} * 1.2778 * \mathrm{~T}_{30 \%}}{(1.5473 * \mathrm{~T})^{0.8246 * \mathrm{~d}_{15}}} \\
-(6.0771 * \mathrm{~T})^{0.0010 /(0.0034 * \mathrm{~T} 30)}\end{array}$ & Fig. 7 & 0.04 & 2.78 & 0.05 & 3.15 & (33) \\
\hline
\end{tabular}




\begin{tabular}{|c|c|c|c|c|c|c|c|c|}
\hline $\begin{array}{c}\mathrm{T} \\
\left({ }^{\circ} \mathrm{C}\right)\end{array}$ & Range & Method & Figure & $\begin{array}{l}\text { AAD } \\
\text { Regression } \\
\left(\mathrm{mm}^{2} / \mathrm{s}\right)\end{array}$ & $\begin{array}{l}\% \text { AAD } \\
\text { Regression }\end{array}$ & $\begin{array}{l}\text { AAD } \\
\text { Test } \\
\left(\mathrm{mm}^{2} / \mathrm{s}\right)\end{array}$ & $\begin{array}{l}\% \text { AAD } \\
\text { Test }\end{array}$ & Eq.\# \\
\hline 150 & $\begin{array}{l}\text { *For Regression ( } 42 \text { data) } \\
\mathrm{KV} \text { from } 0.81 \mathrm{~mm}^{2} / \mathrm{s} \text { to } 1.00 \mathrm{~mm}^{2} / \mathrm{s} \text {; T30 from } 266.08^{\circ} \mathrm{C} \text { to } \\
280.91{ }^{\circ} \mathrm{C} \text {; Specific gravity from } 0.83 \text { to } 0.90 \\
{ }^{*} \text { For Test ( } 10 \text { data) } \\
\mathrm{KV} \text { from } 0.85 \mathrm{~mm}^{2} / \mathrm{s} \text { to } 1.73 \mathrm{~mm}^{2} / \mathrm{s} ; \mathrm{T} 30 \text { from } 272.45^{\circ} \mathrm{C} \text { to } \\
280.91 ;{ }^{\circ} \text { Specific gravity from } 0.85 \text { to } 0.90\end{array}$ & $\begin{array}{l}v_{150} \\
=\frac{2.0081 * \mathrm{~d}_{15} * 0.8882 * \mathrm{~T}_{30 \%}}{(2.0401 * \mathrm{~T})^{0.6350 * \mathrm{~d}_{15}}} \\
-(6.077 \\
* \mathrm{~T})^{0.7820 * 10^{-5} /(0.0056 * \mathrm{~T} 30)}\end{array}$ & Fig. 9 & 0.02 & 2.59 & 0.02 & 2.07 & (34) \\
\hline $\mathrm{T}$ & $\begin{array}{l}\text { *For Regression ( } 273 \text { data) } \\
\mathrm{KV} \text { from } 0.81 \mathrm{~mm}^{2} / \mathrm{s} \text { to } 7.98 \mathrm{~mm}^{2} / \mathrm{s} \text {; T30 from } 214.00^{\circ} \mathrm{C} \text { to } \\
280.91 \text {; }{ }^{\circ} \text { Specific gravity from } 0.83 \text { to } 0.90 \\
{ }^{*} \text { For Test ( } 61 \text { data) } \\
\mathrm{KV} \text { from } 0.85 \mathrm{~mm}^{2} / \mathrm{s} \text { to } 7.88 \mathrm{~mm}^{2} / \mathrm{s} \text {; T30 from } 212.00^{\circ} \mathrm{C} \text { to } \\
280.91 ;{ }^{\circ} \text { Specific gravity from } 0.83 \text { to } 0.90\end{array}$ & $\begin{array}{l}v_{\mathrm{T}} \\
=\frac{1.8744 * \mathrm{~d}_{15} * 1.2115 * \mathrm{~T}_{30 \%}}{(1.6853 * \mathrm{~T})^{0.8103 * \mathrm{~d}_{15}}} \\
-(6.0668 * \mathrm{~T})^{0.0092 /(0.0035 * \mathrm{~T} 30)}\end{array}$ & Fig. 11 & 0.20 & 5.50 & 0.17 & 4.77 & (35) \\
\hline
\end{tabular}


$\mathrm{KV}$ prediction at $\mathrm{T}=20^{\circ} \mathrm{C}$ (regression)

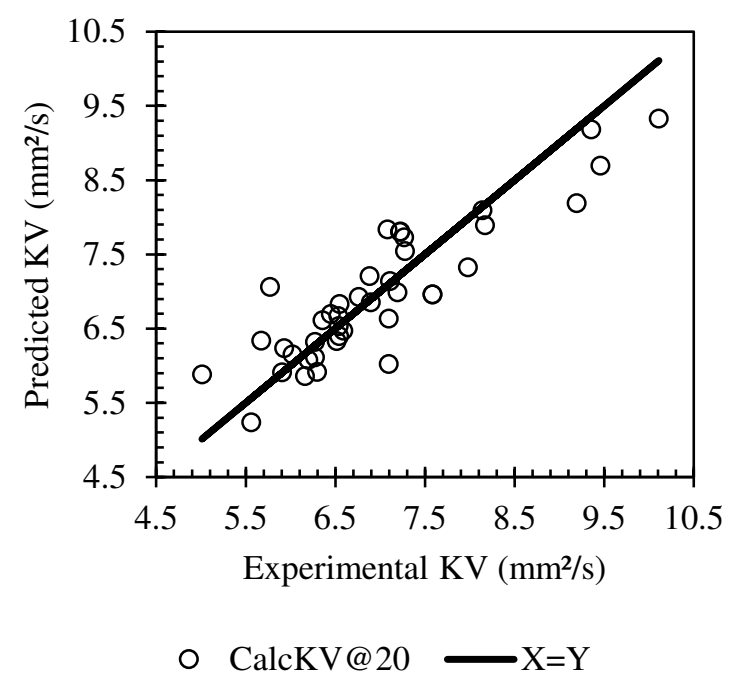

Fig. 1 - KV prediction with training data through Eq.(30)

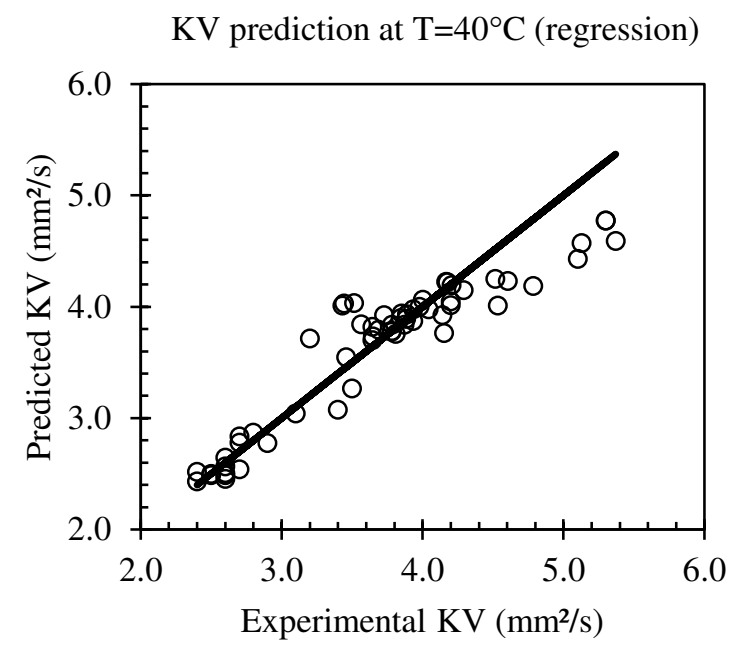

○CalcKV@40 $-\mathrm{X}=\mathrm{Y}$

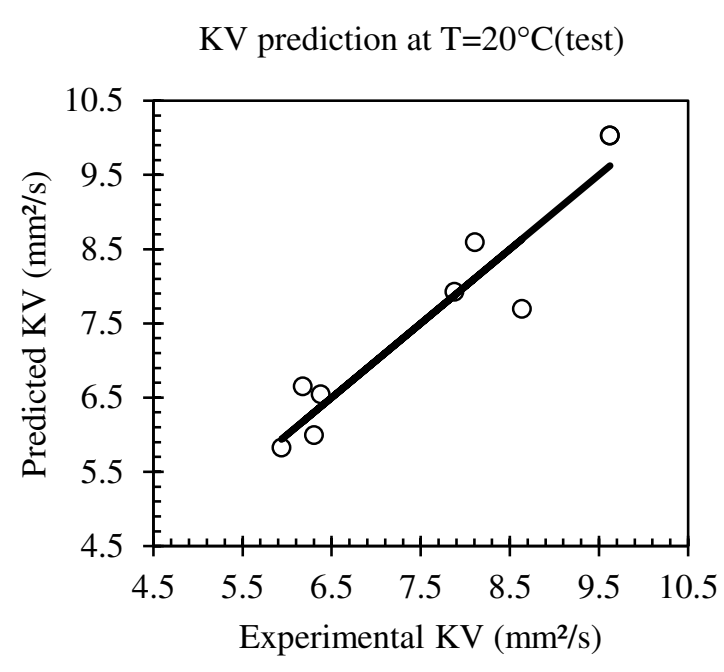

○CalcKV@20 X=Y

Fig. 2 - KV prediction with test data through Eq.(30)

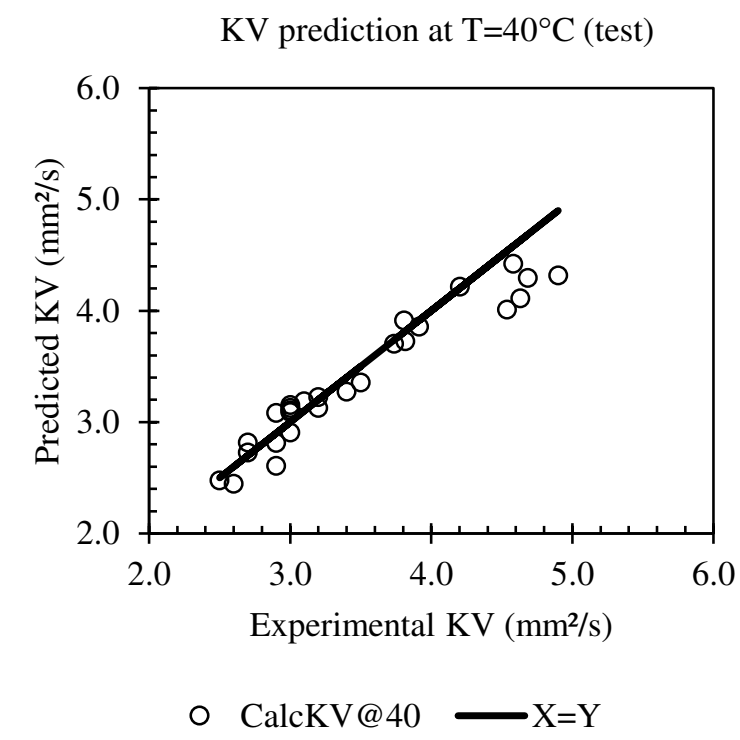

Fig. 3 - KV prediction with training data through Eq.(31)

Fig. 4 - KV prediction with test data through Eq.(31) 
$\mathrm{KV}$ prediction at $\mathrm{T}=50^{\circ} \mathrm{C}$ (regression)

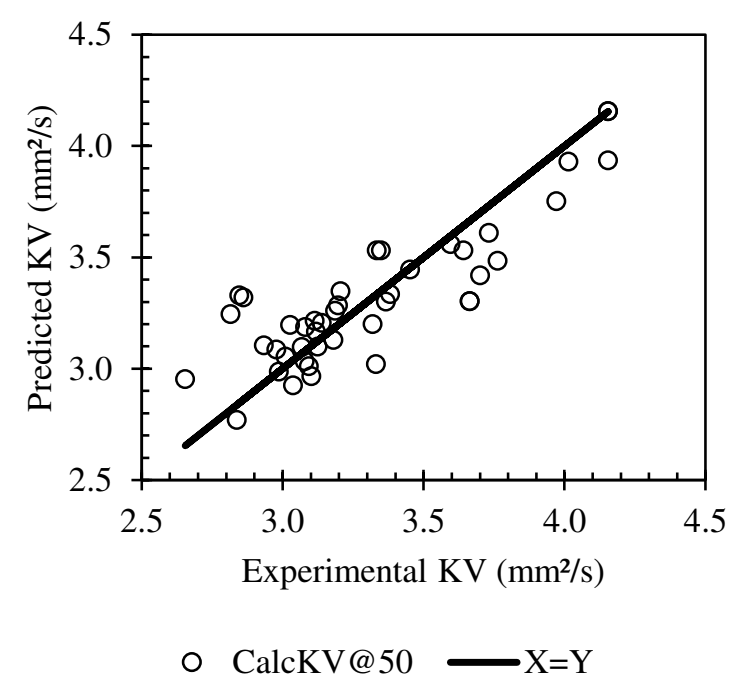

Fig. 5 - KV prediction with training data through Eq.(32)

$\mathrm{KV}$ prediction at $\mathrm{T}=100^{\circ} \mathrm{C}$ (regression)

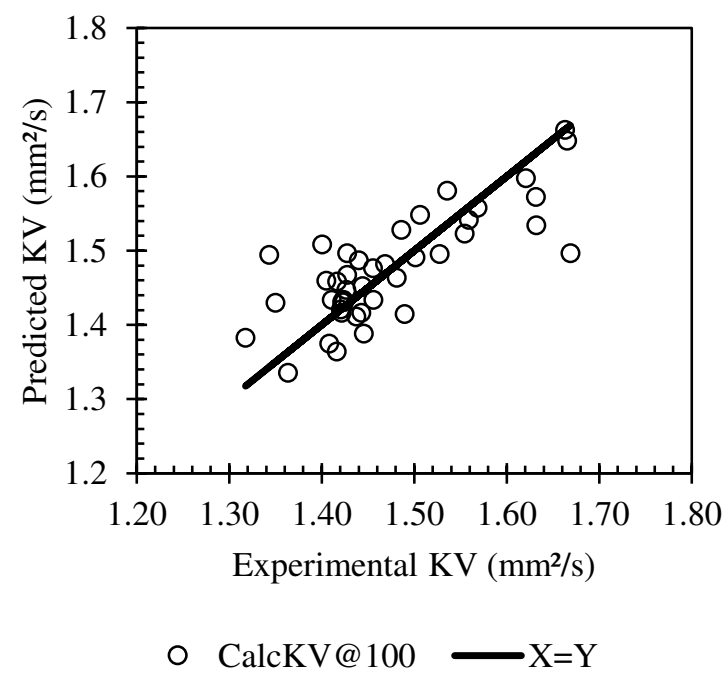

Fig. 7 - KV prediction with training data through Eq.(33)

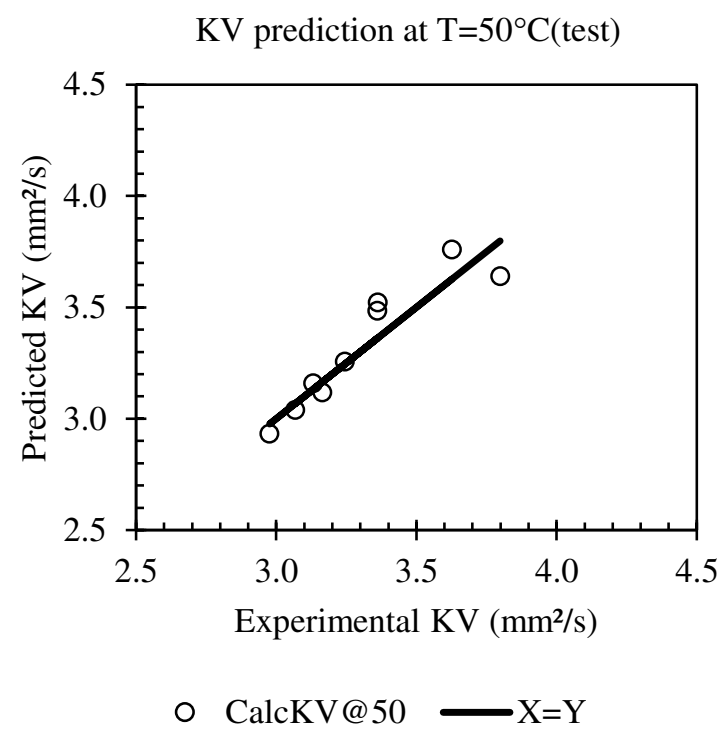

Fig. 6 - KV prediction with test data through Eq.(32)

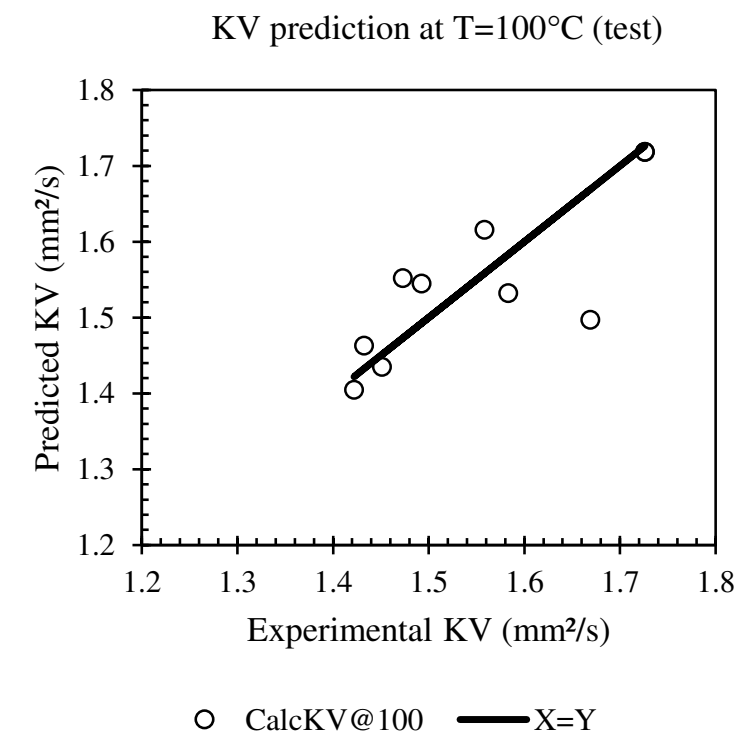

Fig. 8 - KV prediction with test data through Eq.(34) 

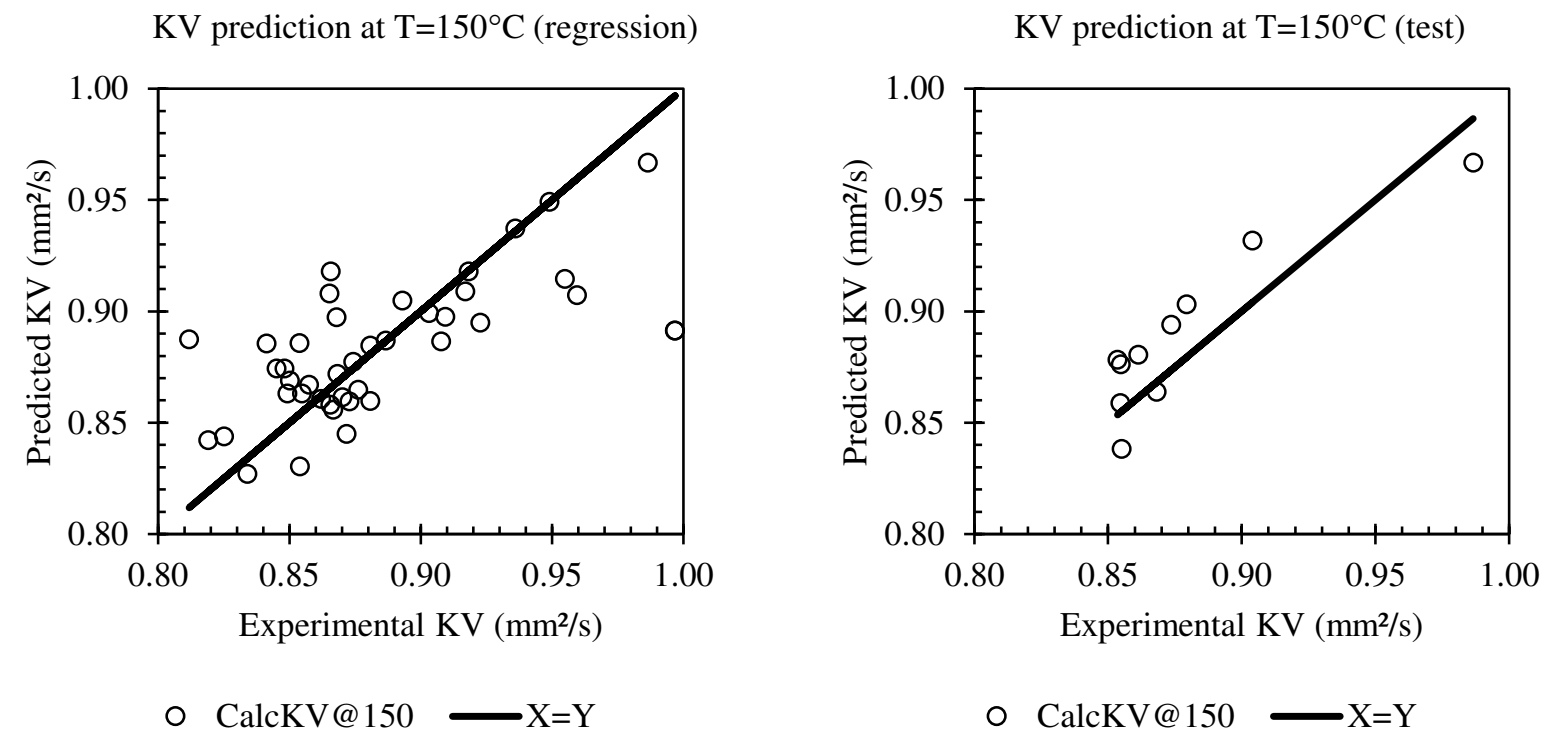

Fig. 9 - KV prediction with training data through Eq.(34)

Fig. 10 - KV prediction with test data through Eq.(34)

$\mathrm{KV}$ prediction at any $\mathrm{T}$ (regression)
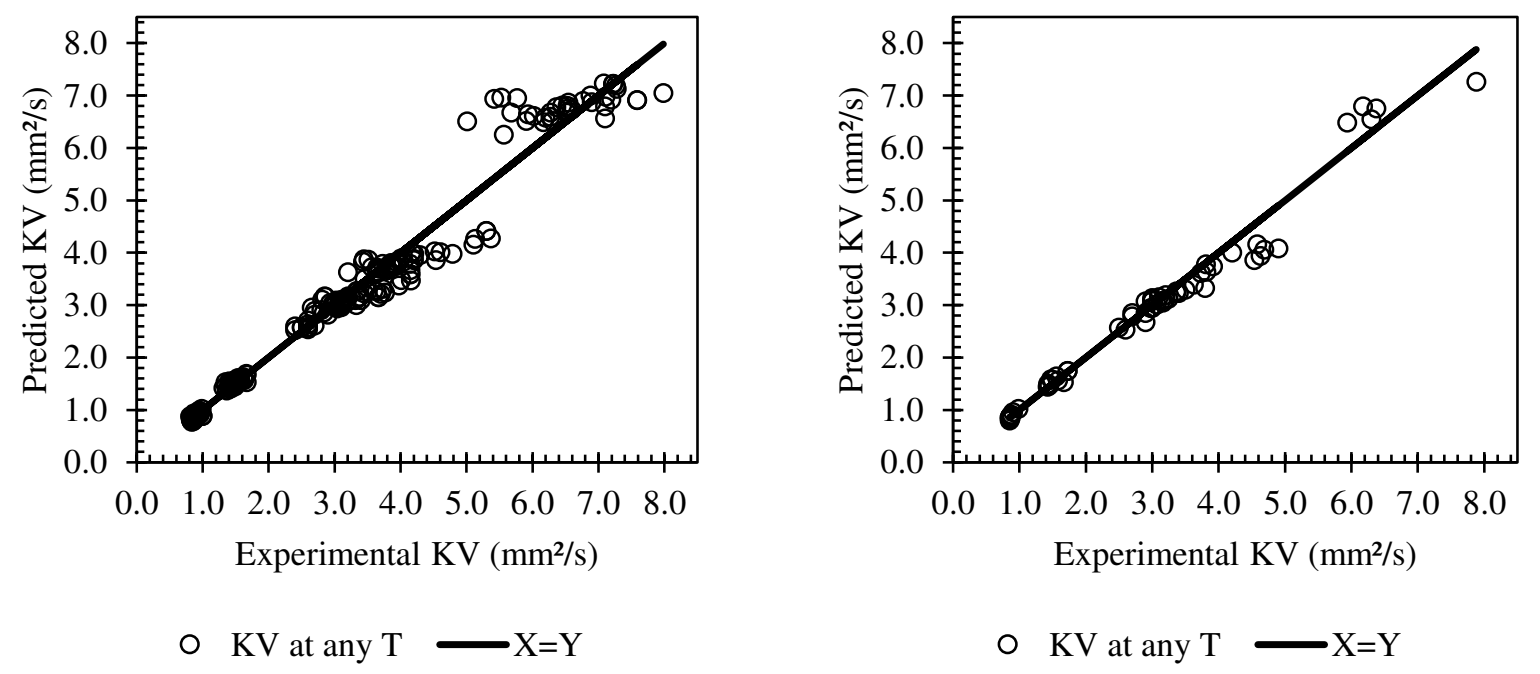

Fig. 11 - KV prediction with training data through Fig. 12 - KV prediction with test data through Eq.(35) Eq.(35) 


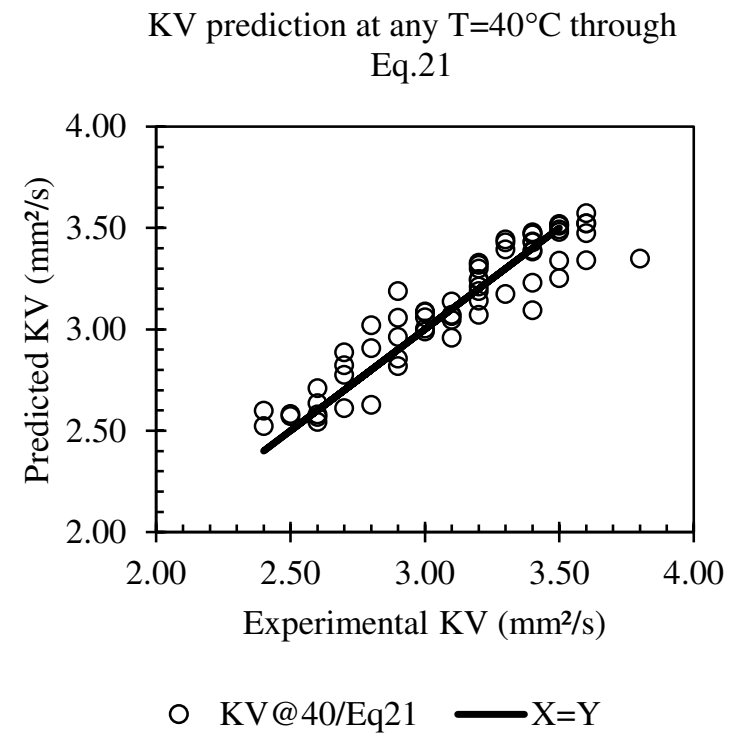

Fig. 13 - Test of Eq.21 through Diesel S500 data
$\mathrm{KV}$ prediction at $\mathrm{T}=40^{\circ} \mathrm{C}$ of diesel $\mathrm{S} 500$ through Eq.17

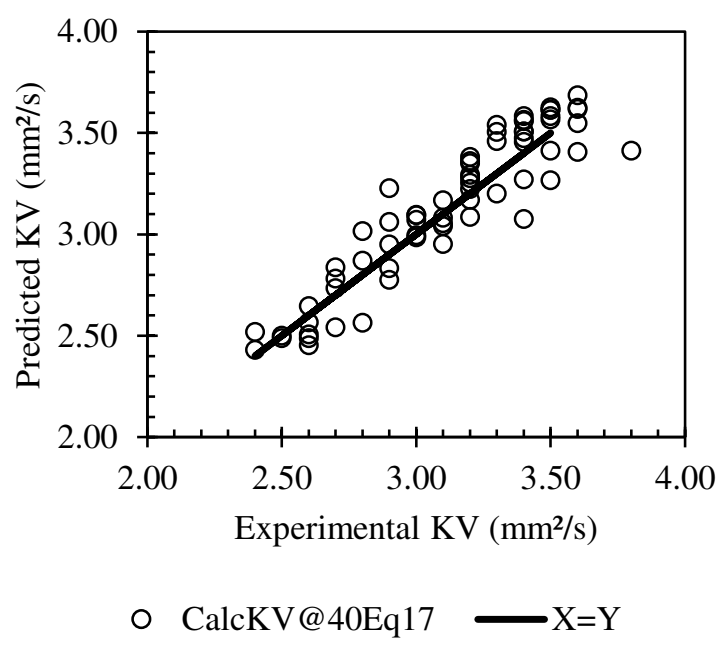

Fig. 14 - Test of Eq.17 through Diesel S500 data

\subsection{Diesel Blends}

To evaluate the most applicable empirical methods to predict KV of diesel-biodiesel blend, we considered four categories of cases, such as $\left(1^{\circ}\right) \mathrm{KV}$ prediction with no criteria of variables (temperature, volume fraction, and feedstock); $\left(2^{\circ}\right) \mathrm{KV}$ prediction regarding volume fraction of biodiesel; $\left(3^{\circ}\right) \mathrm{KV}$ prediction regarding temperature; and $\left(4^{\circ}\right) \mathrm{KV}$ prediction regarding the biodiesel feedstock.

\subsection{1. ( $\left.1^{\circ}\right) K V$ prediction with no criteria of variables (temperature, volume fraction, and feedstock)}

For the first case of study, for models of mixing pure component viscosities, a satisfactory prediction was presented by the model with the minor deviation, which was Arrhenius [51] apud [52], with $\mathrm{AAD}=0.06 \mathrm{~mm}^{2} / \mathrm{s}$ and $\% \mathrm{AAD}=1.62$ (Fig. 15 and Table 1 at Supplementary material). For this case, no criteria was established, considering all biodiesel types (canola, castor, corn, cottonseed, coconut, jatropha, palm, peanut, pomace, rapeseed, sesame, soybean FAME, soybean FAEE, sunflower, waste oil, yellow grease), all temperatures $\left(20^{\circ} \mathrm{C} ; 30^{\circ} \mathrm{C} ; 40^{\circ} \mathrm{C} ; 60{ }^{\circ} \mathrm{C} ; 80{ }^{\circ} \mathrm{C}\right.$; $100{ }^{\circ} \mathrm{C}$ ), all biodiesel volume fractions (2 \%; 5 \%; 7 \%; $10 \% ; 15 \% ; 20 \% ; 25 \% ; 30 \%$; $40 \%$; $50 \%$; $60 \% ; 70 \% ; 75 \% ; 80 \% ; 90 \%$ ), with data from the literature [40], [65], [4], [63], [64], [42], [9], [66]. 
Fig. 15 - Suitable model of mixing pure component viscosities for diesel-biodiesel blend at any $\mathrm{T}$

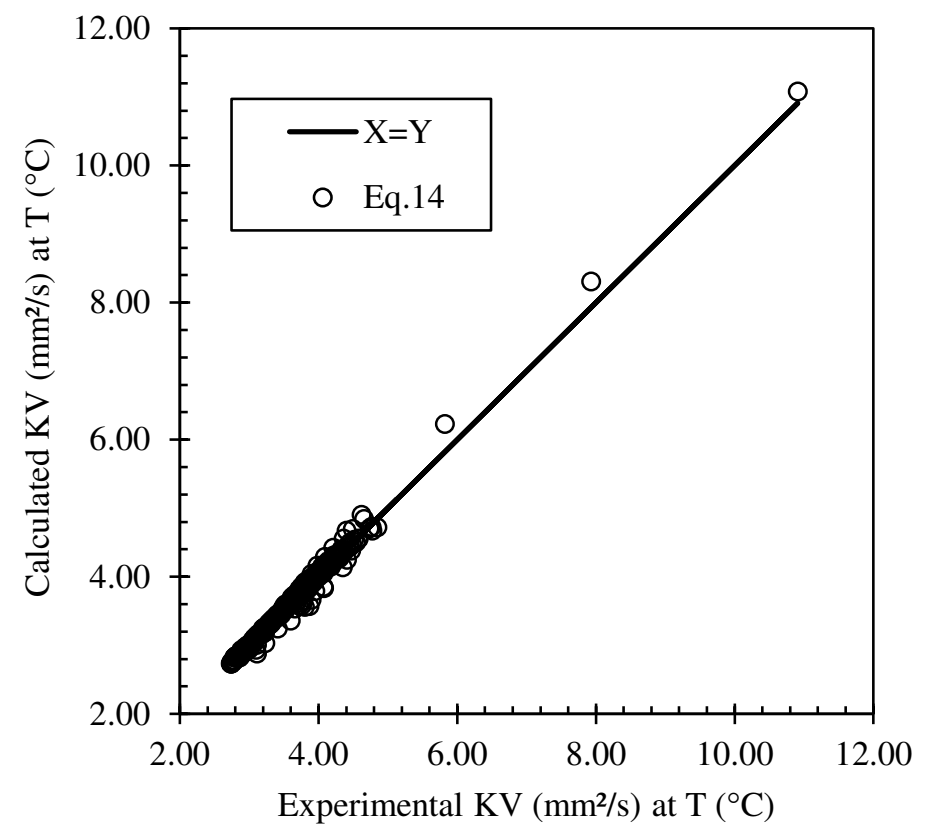

About models with additional parameters, we observed that higher accuracy can be obtained applying them (Table 13). For this case, the most appropriate model was Lederer [60] (Eq.22) with minor deviation \%AAD $=0.73$ applying the parameter $\alpha=0.89$. This model was also indicated as the most accurate by Hernández et al. [44] but for a different system, such as biodiesel-diesel blends at $40^{\circ} \mathrm{C}(\alpha=0.92)$ [44].

Table 13 - Performance of each method with additional parameter - \%AAD - at any temperature

\begin{tabular}{c|c|c}
\hline Model & Any T & Parameter \\
\hline Walther (Eq. 21) & 2.37 & $\mathrm{C}=2.48$ \\
\hline Lederer (Eq. 22) & 0.73 & $\alpha=0.89$ \\
\hline Power (Eq. 24) & 0.77 & $\mathrm{n}=-0.01$ \\
\hline Miadonye et al. (Eq. 25) & 4.21 & $\begin{array}{c}\mathrm{n} \text { is calculated } \\
\text { according to Eq. }\end{array}$ \\
\hline
\end{tabular}




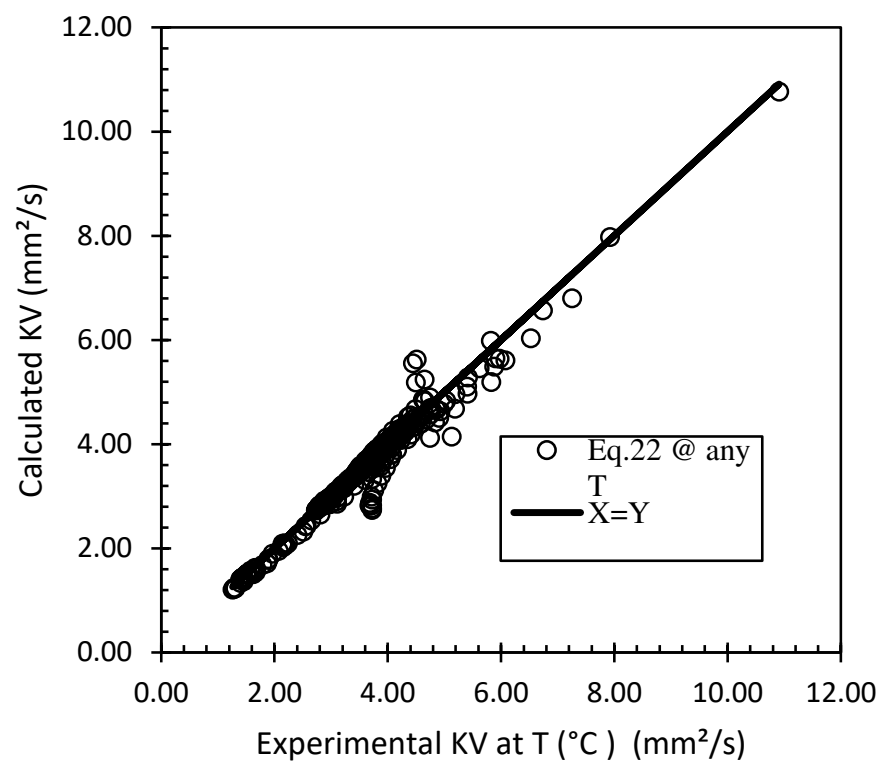

Fig. 16 - Suitable model of additional parameter for diesel-biodiesel blend at any $\mathrm{T}\left(20^{\circ} \mathrm{C}\right.$ to $\left.100^{\circ} \mathrm{C}\right)$

\subsection{2. $\left(2^{\circ}\right) K V$ prediction regarding volume fraction of biodiesel}

To understand the effect of volume fraction for KV prediction, as a second case, we evaluated the predicted $\mathrm{KV}$ at any temperature in three categories, such as biodiesel with volume fraction below $50 \%$; with $50 \%$; and with volume fraction more than $50 \%$. In this case, mixtureviscosity equations presented higher accuracy with minor \%AAD compared to models with additional parameter. We also observed that the lowest accuracy (highest \%AAD) was performed with $50 \%$ of volume fraction of biodiesel and, in general for all methods, the second lowest accuracy was performed with volume fraction of biodiesel more than $50 \%$.

Arrhenius [51] apud [52] model (Eq. (14)) was the most appropriate model for less than $50 \%(\% \mathrm{AAD}=1.49)$ and greater than $50 \%(\% \mathrm{AAD}=1.53)$ of volume fraction of biodiesel. For volume fraction of biodiesel equal to 50\%, the accuracy decreased, and the most appropriate model was Kendal, with \%AAD $=2.37$. Thus, Eq. (14) might be applicable for generalized volume fraction of biodiesel. However, we highlight that the accuracy of Eq. (17), Kendal and Monroe [55] model, can present higher accuracy if one component is dominant in quantity [47]. Also, Eq. (14) presented similar performance for volume fraction of biodiesel equal to 50\%, with \% AAD $=2.59$ (Fig. 17 and Table 2.1 at supplementary material). 
For models with additional parameters, which presented minor deviation considering the specific volume fraction, we observed that the most appropriate model for volume fraction equal to $50 \%$ of biodiesel was performed by Power model [36] (Eq. 24) (\%AAD = 2.76). For volume fraction greater than 50\% of biodiesel, Lederer [60] (Eq. 22) and Power [36] methods were the most suitable, with $\% \mathrm{AAD}=2.30$ and $\% \mathrm{AAD}=2.32$, respectively. Also for volume fraction of biodiesel with less than 50\%, Lederer [60] and Power [36] methods were the most suitable with $\% \mathrm{AAD}=2.27$ for both (Table 2.2 at supplementary material with appropriate parameters).

Further studies with specific data relating volume fraction with temperature is need to better evaluate the influence of both conditions. However, with this evaluation, we observed that kinematic viscosity prediction is influenced by composition, then we suggest to be aware of possibility of greater deviation when biodiesel concentration increases.

$\mathrm{KV}$ prediction at $\mathrm{T}^{\circ} \mathrm{C}\left(\mathrm{mm}^{2} / \mathrm{s}\right)$

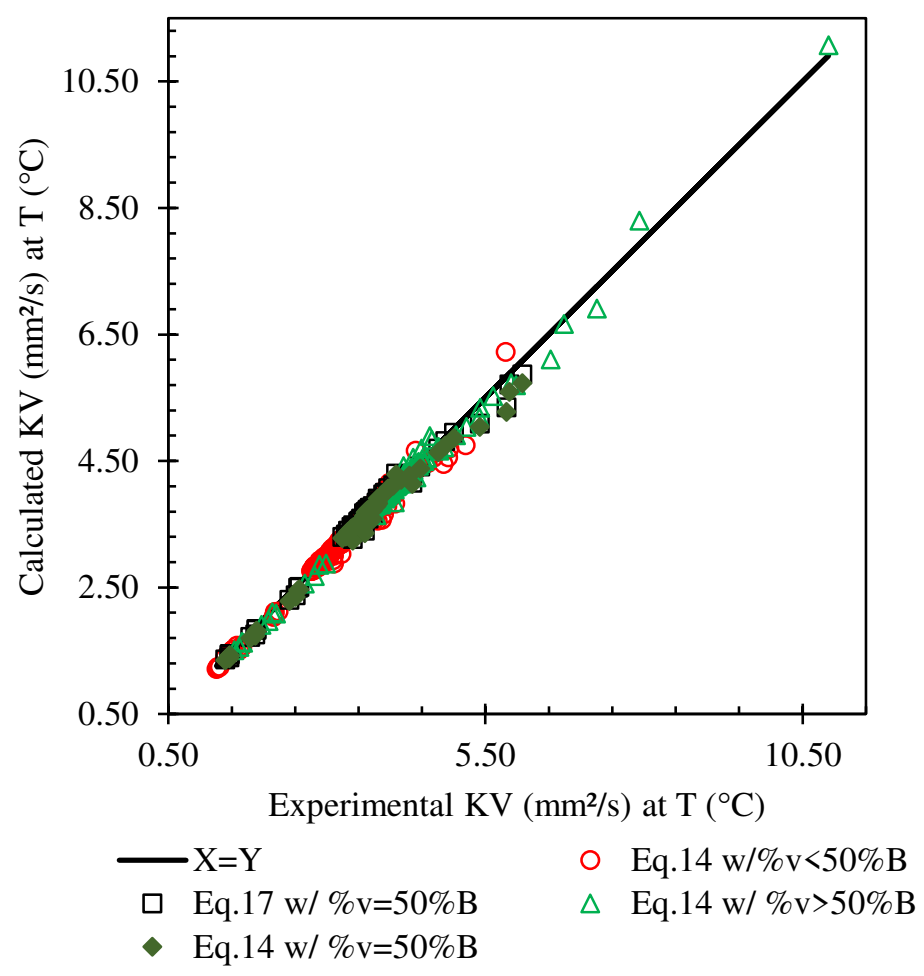

Fig. 17 - Performance of model with the minor deviation, according to volume fraction of biodiesel at any $\mathrm{T}\left({ }^{\circ} \mathrm{C}\right)$ 


\subsection{3. $\left(3^{\circ}\right) \mathrm{KV}$ prediction regarding temperature}

Analyzing the performance according to the temperature, as the third case, we observed that the most appropriate method and its accuracy varies according to the temperature (Table 1 and Table 15).

$\mathrm{KV}$ prediction presented the highest deviation at $20{ }^{\circ} \mathrm{C}$ (almost the double of average deviation, considering all temperatures with $\% A A D=1.62$ ). Since the difference between $\mathrm{KV}$ diesel and $\mathrm{KV}$ biodiesel is almost always the double, regardless of the temperature, we observed that it is not the value of $\mathrm{KV}$ at $20^{\circ} \mathrm{C}$ that affects the prediction result, but it might be the type of model. Hence, $\mathrm{KV}$ prediction at $20^{\circ} \mathrm{C}$ may not be appropriate to apply index mixture models, or $\mathrm{KV}$ at $20^{\circ} \mathrm{C}$ might not follow an additive property performance. Nevertheless, more studies need to be carried out with the same biodiesel source and with the same volume fraction to verify the influence of those parameters. In this study, we could not follow this procedure due to scarcity of data.

Table 14 - Evaluation of predicting methods of KV regarding temperature T

\begin{tabular}{|c|c|c|c|c|c|}
\hline Biodiesel & Model & $\begin{array}{l}\mathbf{T} \\
\left({ }^{\circ} \mathbf{C}\right)\end{array}$ & $\begin{array}{l}\text { \% Volume of } \\
\text { Biodiesel }\end{array}$ & $\begin{array}{c}\text { AAD } \\
\left(\mathbf{m m}^{2} / \mathbf{s}\right)\end{array}$ & \%AAD \\
\hline $\begin{array}{l}\text { canola, castor, corn, cottonseed, jatropha, } \\
\text { palm, soybean, pomace, rapeseed, sesame, } \\
\text { sunflower, waste oil, yellow grease }\end{array}$ & $\begin{array}{l}\text { Cragoe } \\
(\text { Eq. } 15)\end{array}$ & 40 & $\begin{array}{l}2 ; 5 ; 7 ; 10 ; 15 \\
20 ; 25 ; 30 ; 40 \\
50 ; 60 ; 70 ; 75 \\
80 ; 90\end{array}$ & 0.07 & 1.69 \\
\hline coconut, jatropha, waste oil & $\begin{array}{l}\text { Kendal } \\
\text { (Eq. 17) }\end{array}$ & 30 & $\begin{array}{l}5 ; 10 ; 20 ; 40 \\
50 ; 60 ; 75\end{array}$ & 0.04 & 0.92 \\
\hline soybean, yellow grease & $\begin{array}{l}\text { Linear } \\
\text { (Eq. 18) }\end{array}$ & 20 & $25 ; 50 ; 75$ & 0.16 & 2.83 \\
\hline soybean, yellow grease & Linear & 60 & $25 ; 50 ; 75$ & 0.05 & 1.87 \\
\hline $\begin{array}{l}\text { canola, cottonseed, coconut, palm, peanut, } \\
\text { rapeseed, soybean, yellow grease }\end{array}$ & Linear & 80 & $20 ; 25 ; 50 ; 75$ & 0.03 & 1.98 \\
\hline soybean, yellow grease & Linear & 100 & $25 ; 50 ; 75$ & 0.02 & 1.34 \\
\hline
\end{tabular}


After evaluating methods with additional parameter and comparing results (Table 14 and Table 15), we concluded that methods with additional parameters performed higher accuracy than pure mixing methods. In addition, we observed that Lederer [60] method performed satisfactory results for almost all temperatures but for each temperature its parameter has a different value. Depending on the temperature, others also can be applied. We observed that methods with additional parameter performed with minor AAD among specific temperatures such as $30^{\circ} \mathrm{C}$ to $60^{\circ} \mathrm{C}$. Therefore, to obtained the most satisfactory performance, we suggest applying determined methods for a specific temperature (Table 16). We just highlight that due to lack of data, for each temperature, a different type of data (different biodiesel feedstock) were applied. High variety of biodiesel feedstock were used at $40^{\circ} \mathrm{C}$.

Table 15 - Performance of each method with additional parameter - \%AAD - according to the temperature

\begin{tabular}{c|c|c|c|c|c|c}
\hline & \multicolumn{7}{|c}{ \%AAD at specific Temperature $\left({ }^{\circ} \mathbf{C}\right)$ and parameter } \\
\hline Model & $\mathbf{2 0}$ & $\mathbf{3 0}$ & $\mathbf{4 0}$ & $\mathbf{6 0}$ & $\mathbf{8 0}$ & $\mathbf{1 0 0}$ \\
\hline Walther (Eq.21) & $\begin{array}{c}2.83 \\
(\mathrm{C}=6710888.4)\end{array}$ & $\begin{array}{c}0.46 \\
(\mathrm{C}=11.57)\end{array}$ & $\begin{array}{c}2.21 \\
(\mathrm{C}=1.2)\end{array}$ & $\begin{array}{c}1.87 \\
(\mathrm{C}=3399032.36)\end{array}$ & $\begin{array}{c}2.28 \\
(\mathrm{C}=- \\
6699883.19)\end{array}$ & $\begin{array}{c}1.34 \\
(\mathrm{C}=- \\
2488122.3)\end{array}$ \\
\hline Lederer (Eq.22) & $\begin{array}{c}2.24 \\
(\alpha=1.74)\end{array}$ & $\begin{array}{c}0.47 \\
(\alpha=1.19)\end{array}$ & $\begin{array}{c}0.73 \\
(\alpha=0.89)\end{array}$ & $\begin{array}{c}1.41 \\
(\alpha=1.54)\end{array}$ & $\begin{array}{c}1.58 \\
(\alpha=1.54)\end{array}$ & $\begin{array}{c}1.07 \\
(\alpha=1.37)\end{array}$ \\
\hline Power (Eq.24) & $\begin{array}{c}2.79 \\
(\mathrm{n}=1.07)\end{array}$ & $\begin{array}{c}0.46 \\
(\mathrm{n}=0.61)\end{array}$ & $\begin{array}{c}2.21 \\
(\mathrm{n}=-0.1)\end{array}$ & $\begin{array}{c}1.78 \\
(\mathrm{n}=1.37)\end{array}$ & $\begin{array}{c}2.14 \\
(\mathrm{n}=2.20)\end{array}$ & $\begin{array}{c}1.19 \\
(\mathrm{n}=1.35)\end{array}$ \\
\hline Miadonye (Eq.25) & 13.3 & 7.38 & 3.43 & 8.74 & 26.9 & 24.17 \\
\hline
\end{tabular}

Table 16 - The most appropriate method to predict KV of biodiesel-diesel blends considering the temperature

\begin{tabular}{llllll} 
Biodiesel & Model & $\begin{array}{l}\text { T } \\
\left({ }^{\circ} \mathbf{C}\right)\end{array}$ & $\begin{array}{l}\text { \%Volume of } \\
\text { Biodiesel }\end{array}$ & $\begin{array}{c}\text { AAD } \\
\left(\mathbf{m m}^{2} / \mathbf{s}\right)\end{array}$ & \%AAD \\
\hline soybean, yellow grease & Eq.22 $(\alpha=1.74)$ & 20 & $25 ; 50 ; 75$ & 0.13 & 2.24 \\
& $\begin{array}{l}\text { Eq. } 24(\mathrm{n}=0.61) \\
\text { or Eq.21 }(\mathrm{C}=11.57) \text { or } \\
\text { Eq.22 }(\alpha=1.19)\end{array}$ & 30 & $\begin{array}{l}5 ; 10 ; 20 ; 40 ; \\
50 ; 60 ; 75\end{array}$ & 0.03 & 0.47 \\
\hline
\end{tabular}




\begin{tabular}{|c|c|c|c|c|c|}
\hline Biodiesel & Model & $\begin{array}{l}\mathbf{T} \\
\left({ }^{\circ} \mathbf{C}\right)\end{array}$ & $\begin{array}{l}\text { \% Volume of } \\
\text { Biodiesel }\end{array}$ & $\begin{array}{c}\text { AAD } \\
\left(\mathbf{m m}^{2} / \mathbf{s}\right)\end{array}$ & \%AAD \\
\hline $\begin{array}{l}\text { canola, castor, corn, } \\
\text { cottonseed, jatropha, palm, } \\
\text { soybean, pomace, rapeseed, } \\
\text { sesame, sunflower, waste } \\
\text { oil, yellow grease }\end{array}$ & Eq.22 $(\alpha=0.89)$ & 40 & $\begin{array}{l}2 ; 5 ; 7 ; 10 ; 15 \\
20 ; 25 ; 30 ; 40 \\
50 ; 60 ; 70 ; 75 \\
80 ; 90\end{array}$ & 0.03 & 0.73 \\
\hline $\begin{array}{l}\text { soybean, yellow grease } \\
\text { canola, cottonseed, }\end{array}$ & Eq.22 $(\alpha=1.54)$ & 60 & $25 ; 50 ; 75$ & 0.04 & 1.41 \\
\hline $\begin{array}{l}\text { coconut, palm, peanut, } \\
\text { rapeseed, soybean, yellow } \\
\text { grease }\end{array}$ & Eq.22 $(\alpha=1.54)$ & 80 & $20 ; 25 ; 50 ; 75$ & 0.03 & 1.58 \\
\hline soybean, yellow grease & Eq.22 $(\alpha=1.37)$ & 100 & $25 ; 50 ; 75$ & 0.02 & 1.07 \\
\hline
\end{tabular}

\subsection{4. $\left(4^{\circ}\right) K V$ prediction regarding the biodiesel feedstock}

For the fourth case of applying empirical methods of $\mathrm{KV}$ prediction regarding biodiesel feedstock, we observed that there was not only one the most suitable model to be applicable as well. Actually, the most appropriate model varied according to the biodiesel type, as well as temperature (Tables 3.1 and 3.2 at Supplementary Material). However, in general, Lederer [60] method was the method with the minor deviation and for each type of feedstock there is a specific optimum parameter to be applied (Table 17).

On the other hand, the system with the lowest accuracy was that of soybean FAEE biodiesel-diesel blend, with $\mathrm{AAD}=1.04 \mathrm{~mm}^{2} / \mathrm{s}$ and $\% \mathrm{AAD}=22.17$, applying Linear [56] model at $40{ }^{\circ} \mathrm{C}$ (Table 5 at supplementary material). This might imply that the type of alcohol used during transesterification reaction affects the flow property, presenting higher $\mathrm{KV}$, and consequently the accuracy of specific predictive method of KV. More studies might be necessary to verify the prediction of FAEE biodiesel. 
Table 17 - Appropriate method based on feedstock biodiesel and temperature

\begin{tabular}{|c|c|c|c|c|c|}
\hline $\begin{array}{c}\text { Feedstock } \\
\text { biodiesel }\end{array}$ & $\begin{array}{c}\text { Temperature } \\
\left({ }^{\circ} \mathbf{C}\right)\end{array}$ & AAD & \%AAD & Parameter & Method \\
\hline Canola & 40 & $\overline{0.03}$ & 0.74 & 1.72 & Walther \\
\hline Castor & 40 & 0.11 & 1.74 & 0.88 & Lederer \\
\hline Coconut & 30 & 0.02 & 0.45 & 1.14 & Lederer \\
\hline Corn & 40 & 0.03 & 0.84 & - & Refutas \\
\hline Cottonseed & 40 & 0.02 & 0.73 & - & $\begin{array}{c}\text { Chevron } \\
\text { and Cragoe }\end{array}$ \\
\hline Jatropha & 40 & 0.04 & 0.97 & 0.94 & Lederer \\
\hline Jatropha & 30 & 0.01 & 0.29 & 11.57 & Walther \\
\hline Jatropha & $40-30$ & 0.97 & 0.05 & 1.25 & Lederer \\
\hline Palm & 40 & 0.01 & 0.18 & 0.79 & Lederer \\
\hline Pomace & 40 & 0.02 & 0.57 & 0.96 & Lederer \\
\hline Rapeseed & 40 & 0.18 & 4.43 & 27.12 & Walther \\
\hline Sesame & 40 & 0.03 & 0.71 & 0.96 & Lederer \\
\hline Soybean & 20 & 0.13 & 2.22 & 1.80 & Lederer \\
\hline Soybean & 40 & 0.06 & 1.63 & - & $\begin{array}{l}\text { Cragoe, } \\
\text { Chevron, } \\
\text { Refutas, } \\
\text { Chirino, and } \\
\text { Arrhenius }\end{array}$ \\
\hline Soybean & 60 & 0.04 & 1.48 & 1.55 & Lederer \\
\hline Soybean & 100 & 0.02 & 1.03 & 1.37 & Lederer \\
\hline Soybean & 80 & 0.03 & 1.65 & 1.54 & Lederer \\
\hline Soybean & $20-100$ & 0.07 & 2.07 & - & Linear \\
\hline $\begin{array}{l}\text { Soybean } \\
\text { FAEE }\end{array}$ & 40 & 0.67 & 14.00 & 0.72 & Lederer \\
\hline Sunflower & 40 & 0.03 & 0.72 & & $\begin{array}{c}\text { Chevron } \\
\text { and Cragoe }\end{array}$ \\
\hline $\begin{array}{l}\text { Yellow } \\
\text { grease }\end{array}$ & 20 & 0.07 & 1.37 & 1.47 & Lederer \\
\hline $\begin{array}{l}\text { Yellow } \\
\text { grease }\end{array}$ & 40 & 0.04 & 1.24 & 1.40 & Lederer \\
\hline $\begin{array}{l}\text { Yellow } \\
\text { grease }\end{array}$ & 60 & 0.02 & 0.80 & 1.18 & Power \\
\hline
\end{tabular}




\begin{tabular}{c|c|c|c|c|c}
\hline $\begin{array}{c}\text { Feedstock } \\
\text { biodiesel }\end{array}$ & $\begin{array}{c}\text { Temperature } \\
\left({ }^{\circ} \mathbf{C}\right)\end{array}$ & AAD & \%AAD & Parameter & Method \\
\hline $\begin{array}{c}\text { Yellow } \\
\text { grease }\end{array}$ & 80 & 0.02 & 1.09 & 1.82 & Power \\
\hline $\begin{array}{c}\text { Yellow } \\
\text { grease }\end{array}$ & 100 & 0.02 & 1.08 & 1.35 & Power \\
\hline $\begin{array}{c}\text { Yellow } \\
\text { grease }\end{array}$ & $20-100$ & 1.07 & 0.04 & 1.26 & Power \\
\hline
\end{tabular}

One of the most feedstock used for biodiesel production is soybean and we observed different models for each temperature to better predict KV. For any temperature, the most appropriate method was Linear [56] method with minor deviation, \%AAD=2.07 (Fig. 18 and Table 17 and Table 3.1 at supplementary material). Also Lederer [60] method performed satisfactory results with the second minor deviation (\%AAD $=2.40$ with alpha $=0.89)$.

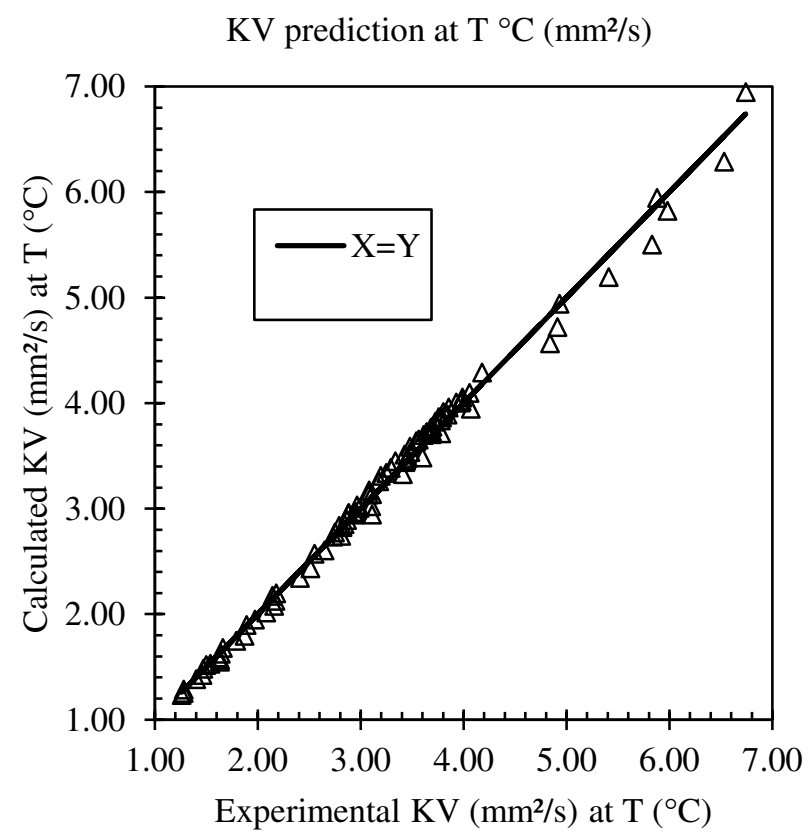

Fig. 18 - KV prediction of biodiesel composed by soybean FAME at any temperature

On the other hand, the system with the lowest accuracy was that of soybean FAEE biodiesel-diesel blend, with $\mathrm{AAD}=1.04 \mathrm{~mm}^{2} / \mathrm{s}$ and $\% \mathrm{AAD}=22.17$, applying Linear [56] model at $40{ }^{\circ} \mathrm{C}$ (Table 5 at supplementary material). This might imply that the type of alcohol used during 
transesterification reaction affects the flow property, presenting higher $\mathrm{KV}$, and consequently the accuracy of specific predictive method of KV. More studies might be necessary to verify the prediction of FAEE biodiesel.

At $40^{\circ} \mathrm{C}$, we observed that the prediction of $\mathrm{KV}$ of soybean FAME blend presented a similar behavior to Cragoe [49] apud [50], Chevron [57], Refutas [56] apud [37], Chirino [48] apud [37], and Arrhenius [51] apud [52] models with the lowest deviation, $\mathrm{AAD}=0.06 \mathrm{~mm}^{2} / \mathrm{s}$ and $\% \mathrm{AAD}=$ 1.6 (Table 18).

Table 18 - Performance of KV prediction at $40{ }^{\circ} \mathrm{C}$ of biodiesel blends with soybean FAME

\begin{tabular}{lrr}
\hline Model & \multicolumn{1}{c}{ AAD } & \%AAD \\
\hline Cragoe & 0.06 & 1.62 \\
Chevron & 0.06 & 1.62 \\
Refutas & 0.06 & 1.62 \\
Chirino & 0.06 & 1.63 \\
Arrhenius & 0.06 & 1.63 \\
Kendal & 0.06 & 1.67 \\
Linear & 0.07 & 1.91 \\
Bingham & 0.07 & 1.95 \\
\hline
\end{tabular}

Finally, we highlight that Refutas [56] apud [37], Chirinos [48] apud [37] and Kendal and Monroe [55] models are not based on volumetric fraction to predict KV for blends. However, precise and similar results were obtained compared to models based on volumetric fraction.

In general, Miadonye et al. [36] and Power [36] models presented the highest deviation, with $\% \mathrm{AAD}=9.55$ and $\% \mathrm{AAD}=8.45$, respectively. However, Miadonye et al. model might have lower accuracy, since it was developed for bitumen. We also highlight that due to lack of density of compounds and/or of mixtures at specific temperatures, Shu [61] method was not evaluated and Walther [37] and Lederer [60] methods were evaluated through volume fraction instead of mass fraction. 


\subsection{Results overview: a KV prediction guide}

As an overview of the results obtained in this assessment, we developed a guide with suggestions of the most appropriate models, regarding minor deviation, to predict kinematic viscosities according to diesel system, its properties, and temperature (Fig. 19).

For diesel fraction at $40^{\circ} \mathrm{C}$, temperature to attend specifications, the most appropriate model was the new Eq.(31) presenting \% AAD = 5.00, or the existing model Eq.(3), with \% AAD = 10.21. For any other temperature, we suggest applying the new Eq.(35), with \%AAD $=5.50$, or the existing model Eq.(6), with \%AAD $=8.22$, or verifying a specific temperature and system at Table 12.

For diesel fraction blend system at $400^{\circ} \mathrm{C}$ (temperature to meet specifications), the most appropriate model was Eq.(31), presenting \% AAD = 5.00, and the existing model Eq.(3), with $\% \mathrm{AAD}=6.69$.

For soybean biodiesel blend system at any temperature, the most appropriate model was Eq.(18), presenting \% AAD $=2.07$. For $\mathrm{KV}$ prediction at $40^{\circ} \mathrm{C}$, we suggest applying some models of pure hydrocarbon mixtures, such as Eq. (13), Eq. (14), Eq. (15), Eq. (19), and Eq. (20), with $\% \mathrm{AAD}=1.63$.

To achieve higher accuracy of KV prediction of diesel-biodiesel blend with a different biodiesel, and also at another temperature different from $40{ }^{\circ} \mathrm{C}$, others models are more suitable (Table 16 and Table 17). In addition, in case of lack of biodiesel KV to be applied on calculations, we suggest consulting a list (Table 7) with average $\mathrm{KV}$ of several biodiesel types at $40^{\circ} \mathrm{C}$, obtained according to the literature.

In this guide, no model was suggested regarding volume fraction, since more studies are needed considering at specific temperature and feedstock biodiesel. However, we highlight that increasing biodiesel volume fraction might decrease the accuracy of these prediction models. 


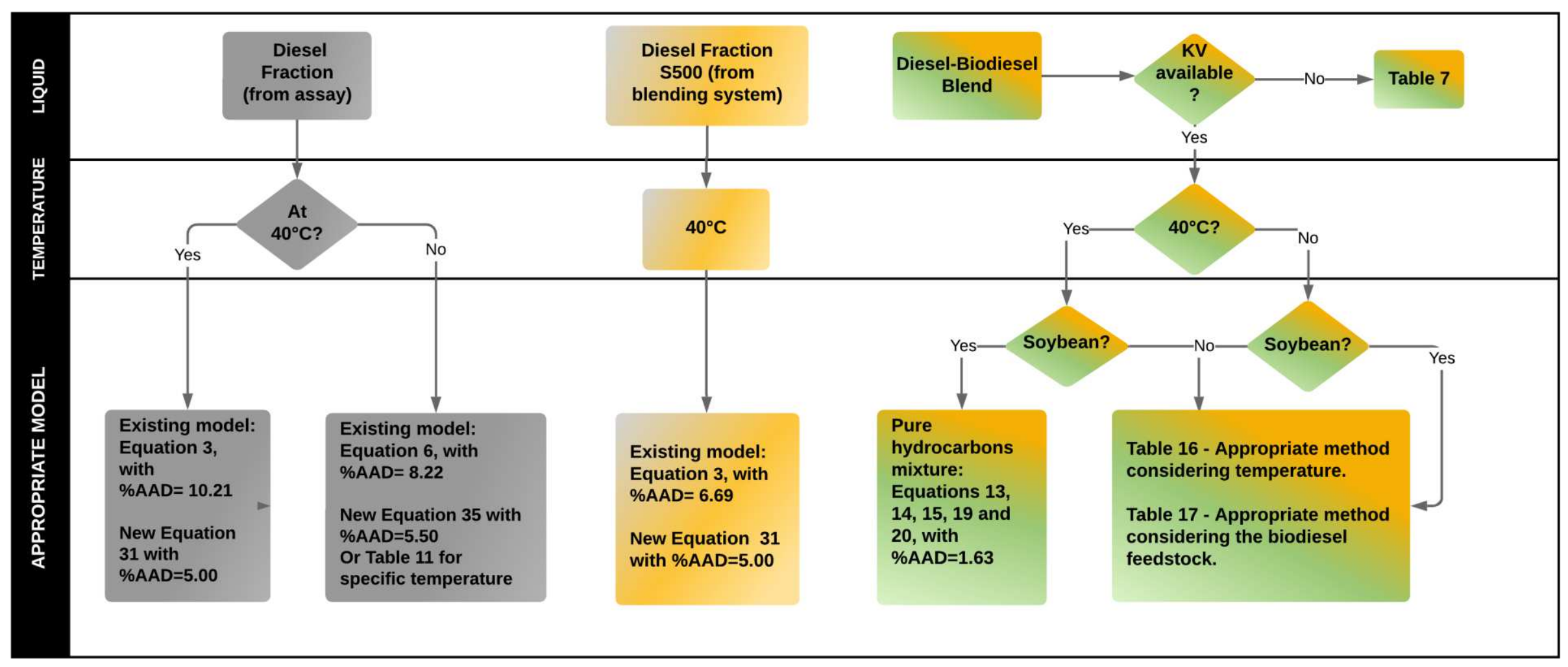

Fig. 19 - Guide for KV prediction with suggested models to apply according to diesel system and temperature 


\section{Conclusion}

In this study, several models of KV prediction were analyzed to different conditions of diesel fraction and diesel blends.

For KV prediction of diesel fraction from petroleum assays, we obtained different behavior and results for each model, according to specific temperature. In another words, even though all models can be applied for any temperature, we identified accuracy variation according to the temperature of kinematic viscosity.

For KV prediction of diesel fraction S500 from blending systems at $40{ }^{\circ} \mathrm{C}$, we observed that Eq. (3) presented a satisfactory accuracy $(\% \mathrm{AAD}=6.69)$

To achieve higher accuracy, we developed new equations for KV at several temperatures, such as $20^{\circ} \mathrm{C}, 40{ }^{\circ} \mathrm{C}, 50{ }^{\circ} \mathrm{C}, 100{ }^{\circ} \mathrm{C}$, and $150{ }^{\circ} \mathrm{C}$, and also for any temperature $\mathrm{T}$ (Table 12 and Fig. 1 to Fig. 12) for diesel fractions. As input for new methods, we studied T10, T30, T50 and specific gravity. We verified that the most satisfactory performance through a nonlinear regression to predict KV are applying T30 and specific gravity. Therefore, only methods with T30 as input were presented in this study. Those methods were tested with different data and provided satisfactory results.

For KV prediction of diesel blends, we considered four categories of cases, such as $\left(1^{\circ}\right) \mathrm{KV}$ prediction with no criteria of variables (temperature, volume fraction, and feedstock); $\left(2^{\circ}\right) \mathrm{KV}$ prediction regarding volume fraction of biodiesel; $\left(3^{\circ}\right) \mathrm{KV}$ prediction regarding temperature; and $\left(4^{\circ}\right) \mathrm{KV}$ prediction regarding the biodiesel feedstock.

As result for the first case, Eq. 14 was the most suitable method for KV prediction, with the minor deviation, $\mathrm{AAD}=0.06 \mathrm{~mm}^{2} / \mathrm{s}$ and $\% \mathrm{AAD}=1.62$.

For considering the study of the impact of volume fraction on $\mathrm{KV}$ prediction as the second case, we evaluated the KV prediction of blend with $50 \%$ of the biodiesel, greater than $50 \%$ of biodiesel and less than $50 \%$ of biodiesel. As results, Eq. 14 was the most accurate method for diesel blend with less and greater than $50 \%$ of biodiesel. For volume fraction of biodiesel equal to $50 \%$ the accuracy is poorer than the other two fractions and presented Eq.17 as the most accurate 
method. For models with additional parameters the higher accuracy was obtained through Eq.22 and Eq. 24.

For the third and fourth case, we observed that the most appropriate method and its accuracy varies according to the temperature and biodiesel feedstock. Therefore, to achieve higher accuracy a specific method must be applied for a specific temperature and feedstock.

We concluded in general that, to obtain the highest accuracy for KV prediction, it is adequate to apply an appropriate model for specific condition and fuel properties. Except in case of soybean biodiesel-diesel blend, any type of KV prediction model (if mixture-viscosity equations or model with additional parameter) can provide similar performance. Also, some models might have their accuracy decreased when the volume fraction of biodiesel increases but more studies must be carried out to verify the influence of the volume fraction on the predictive methods.

Overall, interested researchers can follow the developed guide to choose the most appropriate model for achieving higher accuracy to predict $\mathrm{KV}$ of diesel fraction and its derivatives, according to the object of study, KV range, and temperature.

\section{Nomenclature}

$\begin{array}{ll}\mathrm{KV} & \text { kinematic viscosity } \\ K_{A P I} & \text { API factor } \\ v_{T} & \text { Kinematic viscosity at T temperature } \\ d_{15} & \text { Density at } 15^{\circ} \mathrm{C} \\ A P I & \text { API gravity } \\ T_{b} & \text { Boiling point } \\ A, B & \text { Parameters for liquid related to viscosity } \\ Z & \text { Parameter for viscosity temperature equation } \\ \mathrm{W} & \text { Mass fraction } \\ \mathrm{V} & \text { Volume fraction } \\ \mathrm{x} & \text { Mole fraction } \\ \mathrm{M} & \text { Molar mass }\end{array}$




$\begin{array}{ll}V B I & \text { Viscosity blend index } \\ v_{m} & \text { Mixture kinematic viscosity } \\ \text { AAD } & \text { Average absolute deviation } \\ \% \text { AAD } & \text { Percentage average absolute deviation } \\ v_{D} & \text { Diluent viscosity for Miadonye et al. model } \\ v_{B} & \text { Bitumen viscosity for Miadonye et al. model } \\ \rho_{A}, \rho_{B} & \text { Density for fluid A and B for Shu model } \\ d_{60 F / 60 F^{-}} & \text {Specific gravity at } 60^{\circ} \mathrm{F} / 60^{\circ} \mathrm{F} \\ \mathrm{T} 10, \mathrm{~T} 30, \mathrm{~T} 50 & \text { Temperature at } 10,30 \text { and } 50 \text { vol } \% \text { distilled } \\ \mathrm{T} & \text { Temperature } \\ \text { FAME } & \text { Fatty acid methyl esters } \\ \text { FAEE } & \text { Fatty acid ethyl esters } \\ \mathrm{C} & \text { Walther parameter } \\ \alpha & \text { Alpha, a parameter from Lederer model } \\ \text { a, } \mathrm{n} & \text { Constants from Miadonye additional parameter model }\end{array}$

\section{Acknowledgments}

We thank Petrobras and ANP for providing experimental data and financial support. This study was developed within the scope of the Research, Development, and Innovation program for the petroleum sector, regulated by ANP, under the title "Análise integrada de indicadores de eficiência energética, SMS, econômicos e de processo através do contrato para Modernização e incorporação de novas funcionalidades ao software CalcProc - Suprimento de Macros para cálculo de Processamento de Óleo e Gás Calcproc ("SISTEMA")", project ANP number 20792-8, with Petrobras as the project proponent. We also thank the financial support from Agência Nacional do Petróleo, Gás Natural e Biocombustíveis - ANP - by the ANP Human Resources Program for the Petroleum and Gas Sector - PRH-ANP Convênio FINEP/FUNCAMP, n²9.1, Ref.5485. 


\section{References}

[1] Mehrotra AK, Monnery WD, Svrcek WY. A review of practical calculation methods for the viscosity of liquid hydrocarbons and their mixtures. Fluid Phase Equilib 1996;117:344-55.

[2] Abbott MM, Kaufmann TG, Domash L. A correlation for predicting liquid viscosities of petroleum fractions. Can J Chem Eng 1971;49:379-84. https://doi.org/10.1002/cjce.5450490314.

[3] Tate RE, Watts KC, Allen CAW, Wilkie KI. The viscosities of three biodiesel fuels at temperatures up to 300 8C. Fuel 2006;85:1010-5. https://doi.org/10.1016/j.fuel.2005.10.015.

[4] Alptekin E, Canakci M. Determination of the density and the viscosities of biodiesel-diesel fuel blends. Renew Energy 2008;33:2623-30. https://doi.org/10.1016/j.renene.2008.02.020.

[5] ASTM. ASTM D975-20a Standard Specification for Diesel Fuel. 2020. https://doi.org/10.1520/D0975-20A.

[6] ASTM. D7467 - 20a Standard Specification for Diesel Fuel Oil, Biodiesel Blend (B6 to B20) 1. Am Soc Test Mater 2020. https://doi.org/10.1520/D7467-20A.

[7] Demirbas A. Importance of biodiesel as transportation fuel. Energy Policy 2007;35:466170. https://doi.org/10.1016/j.enpol.2007.04.003.

[8] Sajjadi B, Raman AAA, Arandiyan H. A comprehensive review on properties of edible and non-edible vegetable oil-based biodiesel: Composition, specifications and prediction models. Renew Sustain Energy Rev 2016;63:62-92. https://doi.org/10.1016/j.rser.2016.05.035.

[9] Pham, Minh Tuan; Hoang, Anh Tuan; Le, Anh Tuan; Al-Tawaha, Abdel Rahman M.Said; Dong, Van Huong; Le VV. Measurement and Prediction of the Density and Viscosity of Biodiesel Blends. Int J Technol 2018;5:1015-26. 
https://doi.org/10.14716/ijtech.v9i5.1950.

[10] Gülüm M, Bilgin A. Measurements and empirical correlations in predicting biodieseldiesel blends' viscosity and density. Fuel 2017;199. https://doi.org/10.1016/j.fuel.2017.03.001.

[11] Faria MDC, Valle MLM, Da Cunha Pinto RR. The influence of physico-chemical properties of diesel/biodiesel mixtures on atomization quality in diesel direct injection engines. SAE Tech Pap 2005. https://doi.org/10.4271/2005-01-4154.

[12] ASTM. D6751 - 20 Standard Specification for Biodiesel Fuel Blend Stock (B100) for Middle Distillate Fuels 1. 2020. https://doi.org/10.1520/D6751-20.

[13] Shu WR. A Viscosity Correlation for Mixtures of Heavy Oil, Bitumen, and Petroleum Fractions. Soc Pet Eng J 1984;24:277-82.

[14] Hernández EA, Sánchez-Reyna G, Ancheyta J. Comparison of mixing rules based on binary interaction parameters for calculating viscosity of crude oil blends. Fuel 2019;249:198-205. https://doi.org/10.1016/j.fuel.2019.03.098.

[15] Monnery WD, Svrcek WY, Mehrotra AK. Viscosity: A critical review of practical predictive and correlative methods. Can J Chem Eng 1995;73:3-40. https://doi.org/10.1002/cjce.5450730103.

[16] Kirkwood JG, Buff FP, Green MS. The statistical mechanical theory of transport processes. III. The coefficients of shear and bulk viscosity of liquids. J Chem Phys 1949;17:988-94. https://doi.org/10.1063/1.1747099.

[17] Rice SA, Frisch HL. Some Aspects of the Statistical Theory of Transport. Ann Rev Phys Chem 1960;11:187-272.

[18] Okeson KJ, Rowley RL. A four-parameter corresponding-states method for prediction of Newtonian, pure-component viscosity. Int J Thermophys 1991;12:119-36. https://doi.org/10.1007/BF00506126.

[19] Meier K, Laesecke A, Kabelac S. A Molecular Dynamics Simulation Study of the SelfDiffusion Coefficient and Viscosity of the Lennard-Jones Fluid. Int J Thermophys 
2001;22:161-73. https://doi.org/10.1023/A:1006715921252.

[20] Cao W, Fredenslund A, Rasmussen P. Statistical Thermodynamic Model for Viscosity of Pure Liquids and Liqu. Ind Eng Chem Res 1992;31:2603-19.

[21] Eyring $\mathrm{H}$. Viscosity, plasticity, and diffusion as examples of absolute reaction rates. J Chem Phys 1936;4:283-91. https://doi.org/10.1063/1.1749836.

[22] Viswanath D., Ghosh T, Prasad DHL, Dutt NVK, Rani KY. Viscosity of Liquids - Theory, Estimation, Experiment, and Data. 1st ed. Springer; 2007. https://doi.org/10.1007/978-14020-5482-2.

[23] Eyring H. Viscosity, plasticity, and diffusion as examples of absolute reaction rates. J Chem Phys 1936;4:283-91. https://doi.org/10.1063/1.1749836.

[24] Eyring H, Hirschfelder J. THE THEORY OF THE LIQUID STATE. J Phys Chem 1936;18:249-57.

[25] Ely JF, M Hanley HJ. The Prediction of Transport Properties Viscosity of Fluid and Mixtures. vol. 20. 1981.

[26] Assael MJ, Dymond JH, Papadaki M, Patterson PM. Correlation and Prediction of Dense Fluid Transport Coefficients. III. n-Alkane Mixtures. vol. 13. 1992.

[27] Assael MJ, Dymond JH, Patterson PM. Correlation and prediction of dense fluid transport coefficients. V. Aromatic hydrocarbons. Int J Thermophys 1992;13:895-905. https://doi.org/10.1007/BF00503914.

[28] Aasberg-Petersen K, Knudsen K, Fredenslund A. Prediction of viscosities of hydrocarbon mixtures. Fluid Phase Equilib 1991;70:293-308. https://doi.org/10.1016/03783812(91)85041-R.

[29] ASTM 341-20. ASTM D341 - 20 Standard Practice for Viscosity-Temperature Equations and Charts for Liquid Petroleum or Hydrocarbon Products. 2020. https://doi.org/10.1520/D0341-20.2.

[30] Aboul-Seoud AL, Moharam HM. A generalized viscosity correlation for undefined petroleum fractions. Chem Eng J 1999;72:253-6. https://doi.org/10.1016/S1385- 
8947(98)00131-4.

[31] Amin MB, Beg SA. Generalized kinematic viscosity-temperature correlation for undefined petroleum fractions of ibp $-95^{\circ} \mathrm{c}$ to $455^{\circ} \mathrm{c}+$ boiling ranges. Fuel Sci Technol Int 1994;12:97-129. https://doi.org/10.1080/08843759408916168.

[32] Fang W, Lei Q. Generalized correlation for predicting the kinematic viscosity of liquid petroleum fractions. Fluid Phase Equilib 1999;166:125-39. https://doi.org/10.1016/S03783812(99)00298-8.

[33] Santos S, Fregolente L. Simple and novel models to predict kinematic viscosity and pour point of heavy oil. Rio OIl Gas Conf 2020:0-9.

[34] Santos SM, Nascimento DC, Costa MC, Neto AMB, Fregolente L V. Flash point prediction: Reviewing empirical models for hydrocarbons, petroleum fraction, biodiesel, and blends. Fuel 2020;263. https://doi.org/10.1016/j.fuel.2019.116375.

[35] Hussain I. Generalized Kinematic Viscosity-Temperature Petroleum Fractions S 4 $1988 ; 38$.

[36] Miadonye A, Latour N, Puttagunta VR. Correlation for viscosity and solvent mass fraction of bitumen-diluent mixtures. Pet Sci Technol 2000;18:1-14. https://doi.org/10.1080/10916460008949828.

[37] Centeno G, Sánchez-Reyna G, Ancheyta J, Muñoz JAD, Cardona N. Testing various mixing rules for calculation of viscosity of petroleum blends. Fuel 2011;90:3561-70. https://doi.org/10.1016/j.fuel.2011.02.028.

[38] Ramírez-Verduzco LF, García-Flores BE, Rodríguez-Rodríguez JE, Del Rayo JaramilloJacob A. Prediction of the density and viscosity in biodiesel blends at various temperatures. Fuel 2011;90:1751-61. https://doi.org/10.1016/j.fuel.2010.12.032.

[39] Pramanik K. Properties and use of jatropha curcas oil and diesel fuel blends in compression ignition engine. Renew Energy 2003;28:239-48. https://doi.org/10.1016/S0960-1481(02)00027-7.

[40] Ejim CE, Fleck BA, Amirfazli A. Analytical study for atomization of biodiesels and their 
blends in a typical injector: Surface tension and viscosity effects. Fuel 2007;86:1534-44. https://doi.org/10.1016/j.fuel.2006.11.006.

[41] Joshi RM, Pegg MJ. Flow properties of biodiesel fuel blends at low temperatures. Fuel 2007;86:143-51. https://doi.org/10.1016/j.fuel.2006.06.005.

[42] Kanaveli IP, Atzemi M, Lois E. Predicting the viscosity of diesel/biodiesel blends. Fuel 2017;199:248-63. https://doi.org/10.1016/j.fuel.2017.02.077.

[43] Ramírez Verduzco LF. Density and viscosity of biodiesel as a function of temperature: Empirical models. Renew Sustain Energy Rev 2013;19:652-65. https://doi.org/10.1016/j.rser.2012.11.022.

[44] Hernández EA, Sánchez-Reyna G, Ancheyta J. Evaluation of mixing rules to predict viscosity of petrodiesel and biodiesel blends. Fuel 2021;283:118941. https://doi.org/10.1016/j.fuel.2020.118941.

[45] American Petroleum Institute. Technical Data Book American Petroleum Institute. Am Pet Inst 1997.

[46] Beg SA, Amin MB, Hussain I. Generalized kinematic viscosity-temperature correlation for undefined petroleum fractions. Chem Eng J 1988;38:123-36. https://doi.org/10.1016/0300-9467(88)80068-6.

[47] VISWANATH, DABIR S.; GHOSH, TUSHAR K.; PRASAD, DASIKA H. L.; DUTT, NIDAMARTYV. K.; RANI KY. Viscosity of Liquids: Theory, Estimation, Experiment, and Data -. 2007.

[48] Chirinos M, Gonzalez J, Layrisse I. Rheological properties of crude oils from the orinoco oil belt and their mixtures with diluents. Rev Tec Intevep 1983;32:103-15.

[49] Al-Maamari RS, Vakili-Nezhaad G, Vatani M. Experimental and Modeling Investigations of the Viscosity of Crude Oil Binary Blends: New Models Based on the Genetic Algorithm Method. vol. 12. 2015.

[50] Zhang L, Zhang L, Xu Z, Guo X, Xu C, Zhao S. Viscosity Mixing Rule and Viscosityerature Relationship Estimation for Oil Sand Bitumen Vacuum Residue and 
Fractions. Energy and Fuels 2019;33:206-14.

https://doi.org/10.1021/acs.energyfuels.8b03511.

[51] Arrhenius S. Über die innere Reibung verdünnter wässeriger Lösungen. Zeitschrift Für Phys Chemie 1887;1.

[52] Rahmes MH, Nelson WL. Viscosity Blending Relationships of Heavy Petroleum Oils. Anal Chem 1948;20:912-5. https://doi.org/10.1021/ac60022a012.

[53] Jones H, Bingham E. The Conductivity and Viscosity of Solutions of Certain Salts in Mixtures of Acetone with Methyl Alcohol, with Ethyl Alcohol and Water. Am Chem J 1905;34:481-554.

[54] Nagasawa K, Suzuki T, Seto R, Okada M, Yue Y. Mixing sauces: A viscosity blending model for shear thinning fluids. ACM Trans Graph 2019;38:1-17. https://doi.org/10.1145/3306346.3322947.

[55] Kendal, James; Monroe KP. THE VISCOSITY OF LIQUIDS. III. IDEAL SOLUTIONS OF SOLIDS IN LIQUIDS.1. J Am Chem Soc 1917;39:1802-1086.

[56] Baird CT. Crude oil yields and product properties. 1222 Vezenaz, Geneva,Switzerland: Ch. De la Haute-Belotte 6, Cud Thomas Baird IV; 1981.

[57] Riazi MR. Characterization and Properties of Petroleum Fractions. 1st ed. West Conshohocken: ASTM International; 2005.

[58] Cragoe C. Changes in the viscosity of liquids with temperature, pressure and composition. Process World Pet. Congr., 1933, p. 529-41.

[59] Pallares FR. The Viscosity and Thermal Conductivity of Heavy Oils and Solvents. Calgary, Doctoral Thesis University of Calgary: 2017. https://doi.org/10.11575/PRISM/28417.

[60] Nourozieh H, Kariznovi M, Abedi J. Density and viscosity of athabasca bitumen, a condensate sample, and mixtures applicable for expanding-solvent steam-assisted-gravitydrainage and liquid-addition-to-steam-for-enhancing-recovery processes. Soc Pet Eng 2017;20:937-56. https://doi.org/10.2118/185952-pa. 
[61] Lederer E. Viscosity of mixtures with and without diluents. Proc World Pet Cong London 1933.

[62] Exxon Mobil. Assays available for download | ExxonMobil 2020. https://corporate.exxonmobil.com/Crude-oils/Crude-trading/Assays-available-fordownload (accessed June 22, 2020).

[63] Tesfa B, Mishra R, Gu F, Powles N. Prediction models for density and viscosity of biodiesel and their effects on fuel supply system in CI engines. Renew Energy 2010;35:2752-60. https://doi.org/10.1016/j.renene.2010.04.026.

[64] Mejía JD, Salgado N, Orrego CE. Effect of blends of Diesel and Palm-Castor biodiesels on viscosity, cloud point and flash point. Ind Crops Prod 2013;43:791-7.

https://doi.org/10.1016/j.indcrop.2012.08.026.

[65] Candeia RA, Silva MCD, Carvalho Filho JR, Brasilino MGA, Bicudo TC, Santos IMG, et al. Influence of soybean biodiesel content on basic properties of biodiesel-diesel blends. Fuel 2009;88:738-43. https://doi.org/10.1016/j.fuel.2008.10.015.

[66] Yuan, Wenqiao; Hansen, Alan C.; Zhang, Qin; Tan Z. Temperature-dependent kinematic viscosity of selected biodiesel fuels and blends with diesel fuel. JAOCS, J Am Oil Chem Soc 2005;82:195-9. https://doi.org/10.1007/s11746-005-5172-6. 


\section{Supplementary Files}

This is a list of supplementary files associated with this preprint. Click to download.

- Graphicalabstract9.png

- SUPPLEMANTARYMATERIAL.pdf 